\title{
تأثير الطباعة على الخواص الأدائية للأقمششة الصناعية
}

Printing effect on the performance characteristics

\section{of the Industrial Fabrics}

د/ رشا محمد نجيب مبارك

مدرس الملابس و النسيج

بقسم الاقتصاد المنزلى
أ.د/ حنان حسنى بشار احمد

استاذ الملابس و النسيج بقسم الاقتصاد

المنزلى ووكيل الكلية لثئون التعليم و الطلاب

\section{شادية نسيم الحلفاوى \\ ملخص البحث: بكالوريوس الاقتصاد المنزلى قسم المابس و النسيج}

تتعرض الأقشة أثناء استخدامها إلى أثنكال متعددة من مظاهر التشوه نتيجة

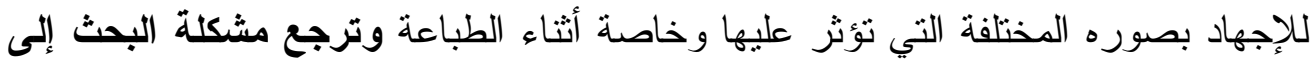
: أن الطباعة اليدوية تعتمد علي المهارة العالية و الحس الفني الدقيق، وقد أكدت هذا كثثر ماهد من الدراسات في مجال الطباعة اليدوية و التي أكدت انه يمكن تتمية المعارف و والمهار ات المتعلقة بالطباعة اليدوية فتختلف الأقشة من حيث مدي ثأثثرها بالطباعة المستخدمة

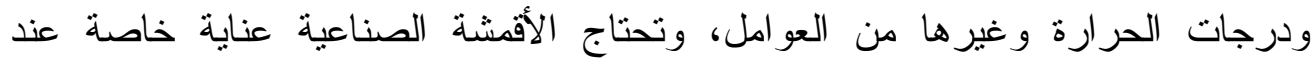

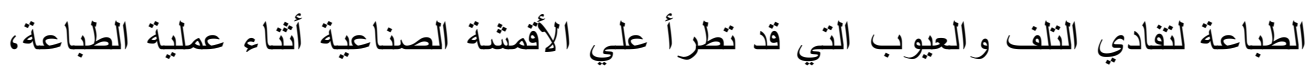

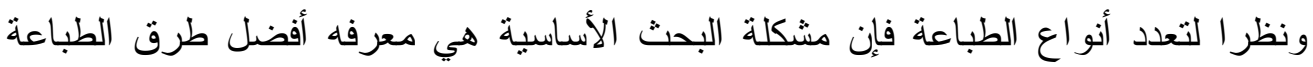

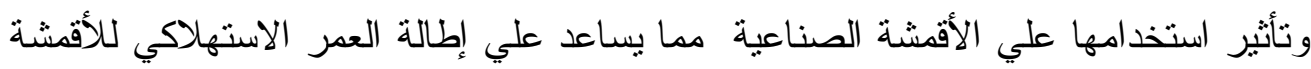
الصناعية.

علي ضوء ما تقدم يمكن صياغة مشكلة البحث في التساؤل الرئيسي التالي :

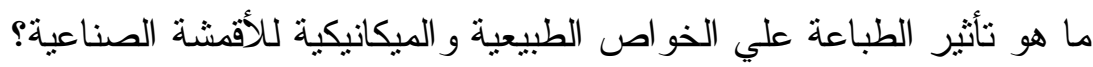
ولقد توصل البحث إلى: وقد أثرت الطباعة على وزن جميع أنواع الأقمشة وبكل طرق الطباعة وز ادت كل أنواع

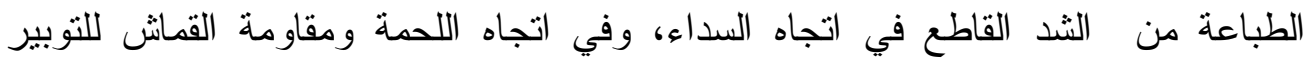
(التكور ) ، و أيضاً ز ادت مقاومة نفاذية الهو اء. 


\section{Research Summary:}

Exposed fabrics during use to multiple forms of manifestations of deformation as a result of stress different manner that affects them, especially during printing due research problem to: the hand-printing depends on the skill of high artistic sense flour, has this many studies confirmed in a hand-printing area, which confirmed that he could knowledge and skills related to manual printing development vary fabrics in terms of the impact printing used and the temperatures and other factors, and you need industrial fabrics special care when printing to avoid damage and defects that may occur on a fabric industry during the printing process, due to the multiple types of printing the problem of basic research is to find out better methods of printing and the impact of their use on the industrial fabrics, which helps to prolong the life of the consumer and industrial fabrics.

In light of the progress of the research problem can be formulated in the following main question:

What is the impact of printing on the mechanical properties of natural and industrial fabrics?

We have come to search:

Printing on the weight of all kinds of fabrics and has influenced all methods of printing and increased print all types of tensile cutter in the warp direction, and the direction of the weft and the resistance of the cloth topper (balling), and also increased resistance to air permeability. 


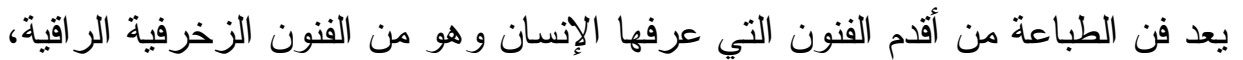

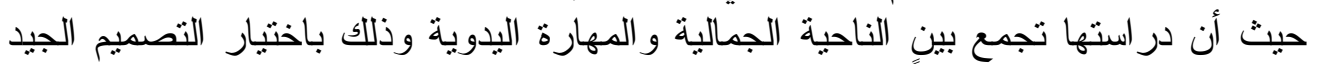

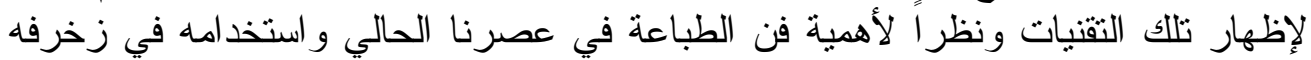

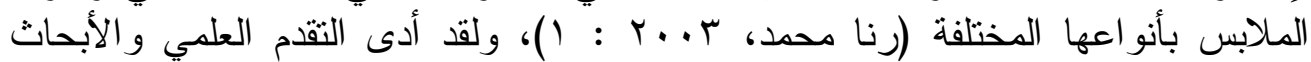

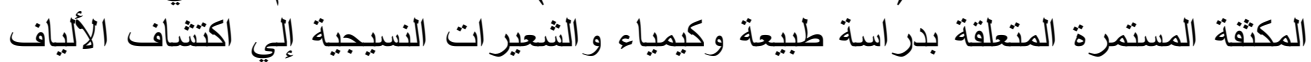

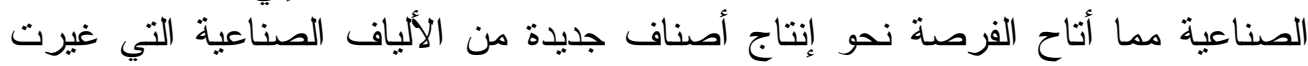

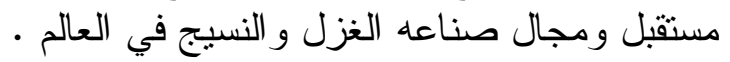

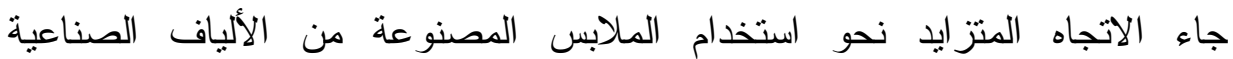

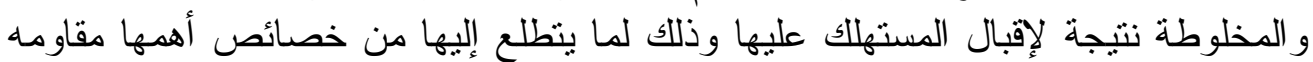

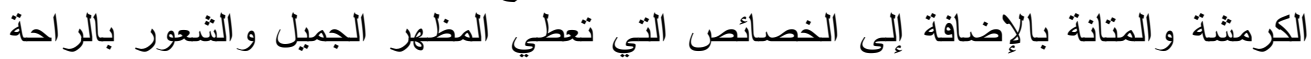

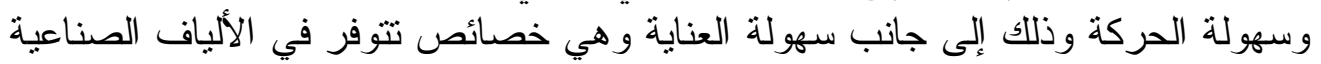
و المخلوطة أكثر منها في الألياف الطبيعية ( إيمان حامد، ج ـ . ب : 1 ) ).

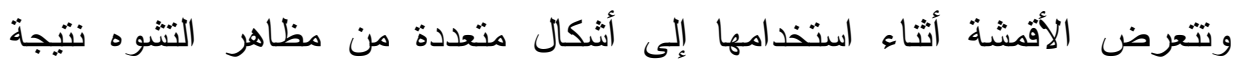

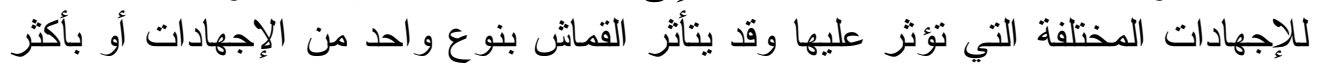

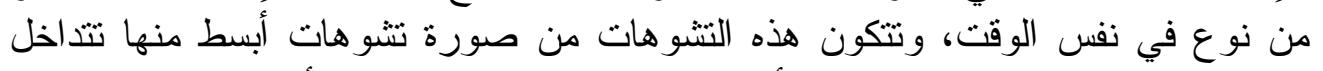

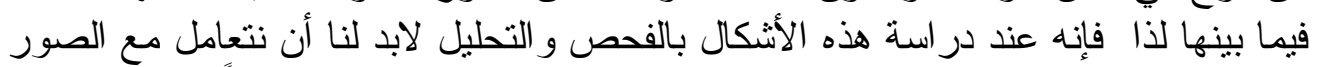

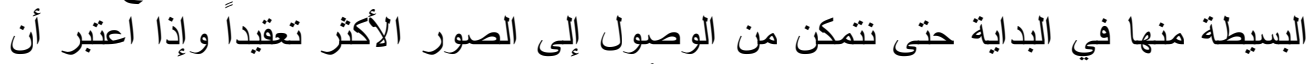

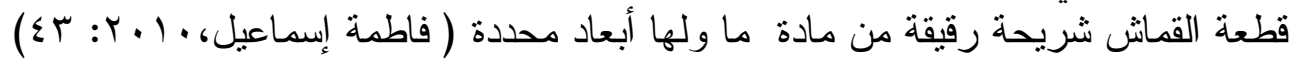
ترجع مشكلة البحث إلى: أن الطباعة اليدوية للمنسوجات تعتمد علي المهارة العالية

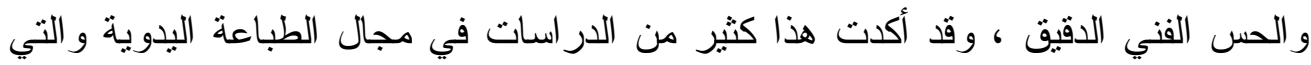

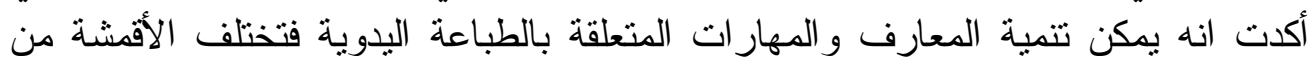

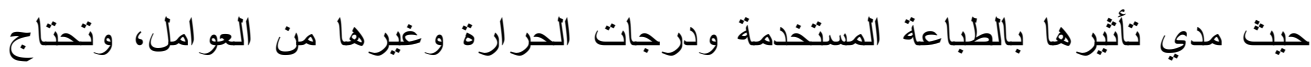

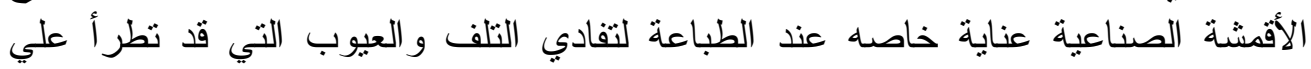

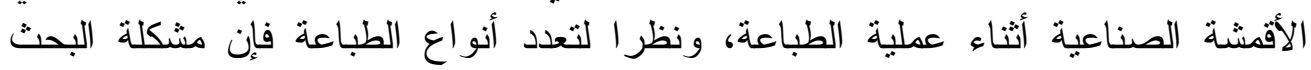

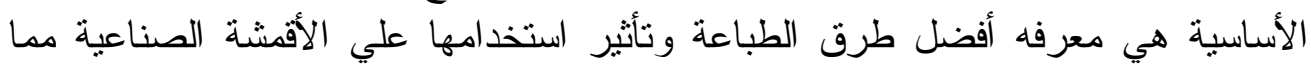

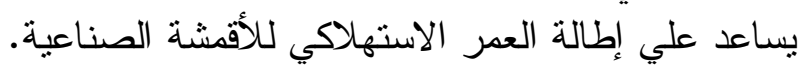

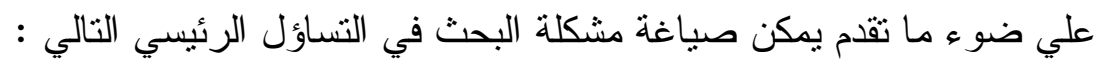

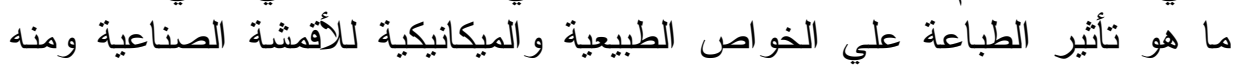
يتفرع التساؤلات التالي: تأليز

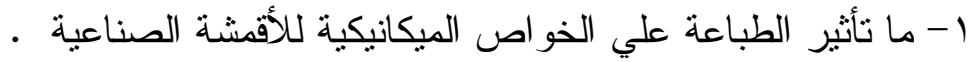

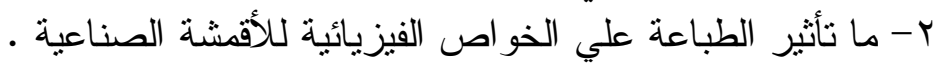

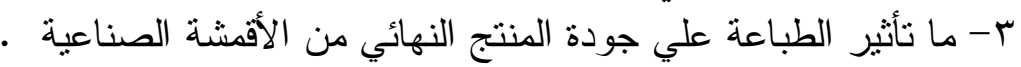




\section{أهمية البحث : ترجع أهمية البحث إلي :}

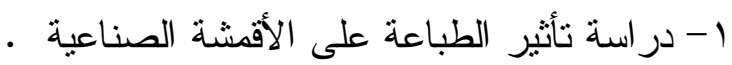

r- التعرف على أنسب طرق طباعة الأقمشة الصناعية .

\section{هدف البحث : يهدف هذا البحث إلى :}

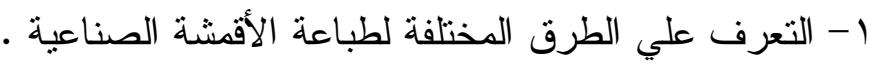

r- در اسة أثز المتغير ات المرتبطة بعملية الطباعة على خصائص الأقشة الصنة الصناعة الصناعية.

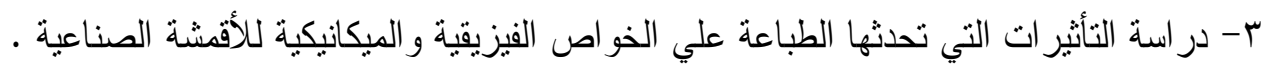

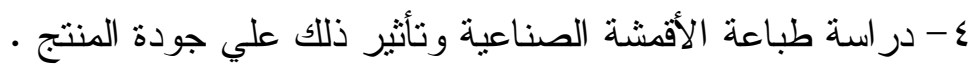

\section{حدود البحث :}

الأقمشة المستخدمة : أقمشة من ألياف البولي أستر .

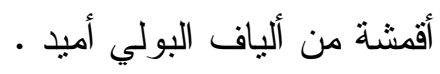

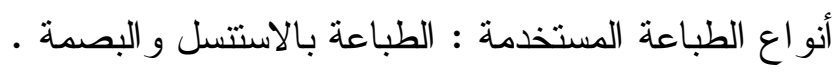

\section{منهج البحث :}

لتحقيق أهداف الدر اسة انبعت الباحثة المنهج الوصفي و المنهج التجريبي .

\section{فروض البحث :}

- - توجد فروق ذات دلالة إحصائية بين منوسطات درجات تأثنر نوع الطباعة علي

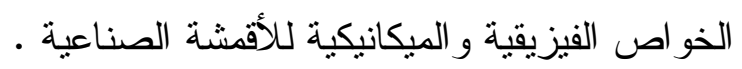
ץ- نوجد فروق ذات دلاله إحصائية بين منوسطات درجات نأثير نوع الطية الطباعة واتئة والألوان

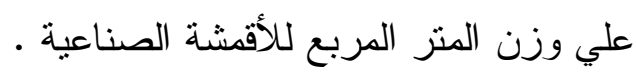

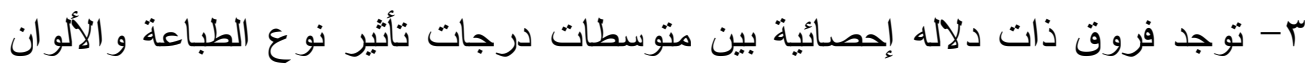

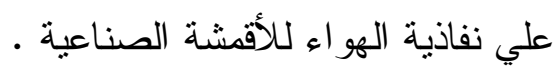

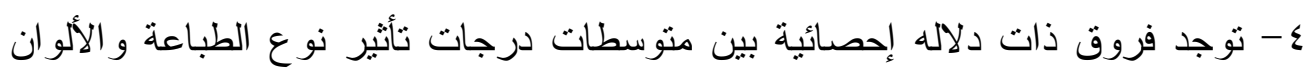
علي قوة التمزق للأقششة الصناعية . ه- توجد فروق ذات دلاله إحصائية بين متوسطات درجاتية لـات تأثير نوع الطباعة والألوان

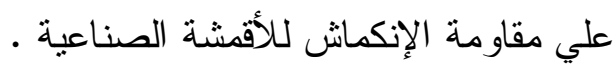

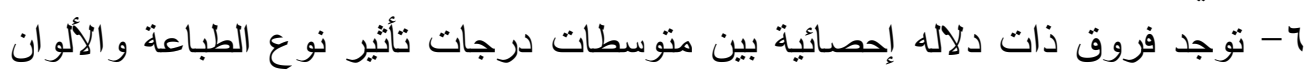

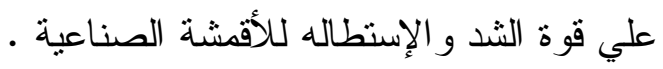




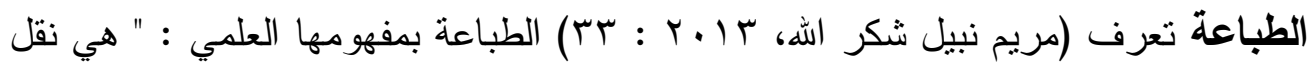

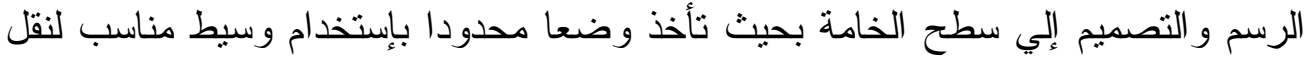

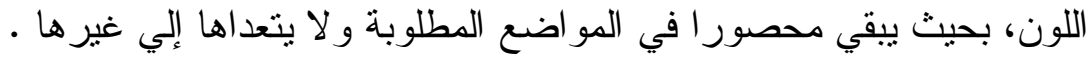

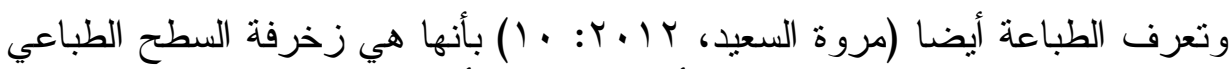

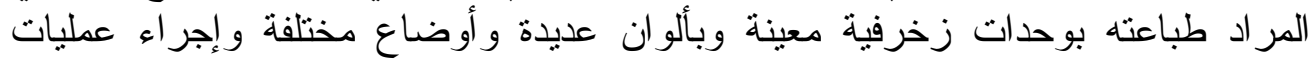

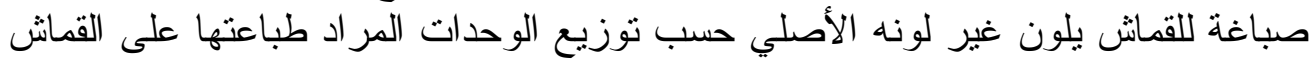

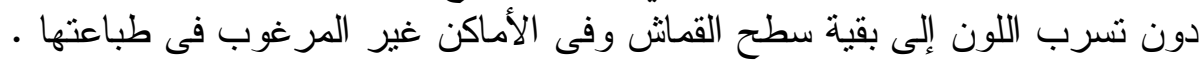

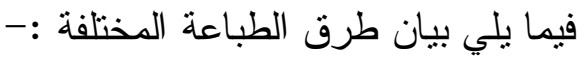

Block printing

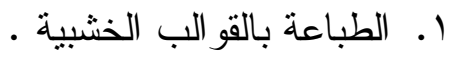

Roller Printing

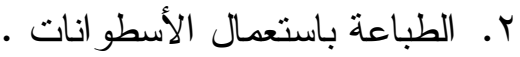

Duplex Printing

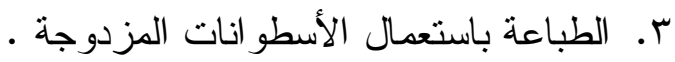

Discharge Printing ع. ـ طباعة بالإز الة . . ل

Resist Printing ه. الطباعة بالمناعة .

Stencil Printing

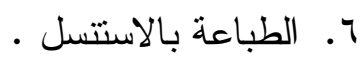

Silk Screen Printing

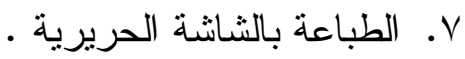

Warp Printing

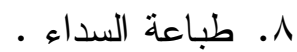

Photo Printing 9. الطباعة بالتصوير لاعهاع

Batik dyeing . 1.1.

Tie dyeing

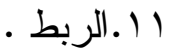

الخواص الأدائية : أثر الخواص الطبيعية والميكانيكية المختلفة علي إكساب المنتج النهائي

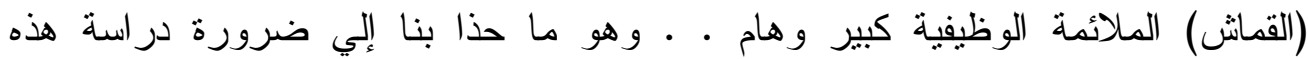

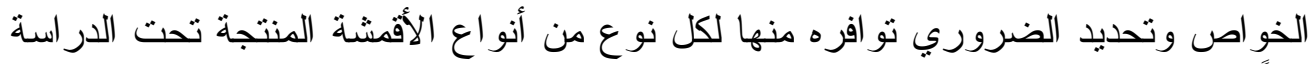

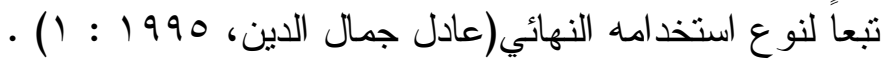
تعتبر طباعة المنسوجات من أهم الطرق المستخدمة لإدخال اللون و التصميم للمنسوجات حيث كانت هناك رغبة لإنتاج ملابس تعكس جمال الطبيعة وكذللك إحساس الإس الطال الفنانين المرهف منذ البداية وقت طباعة المنسوجات ليس وليد التكنولوجيا الحديثة فقط.

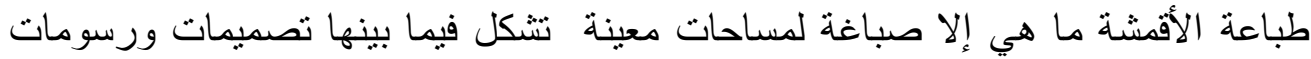

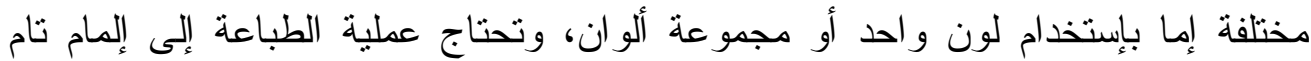

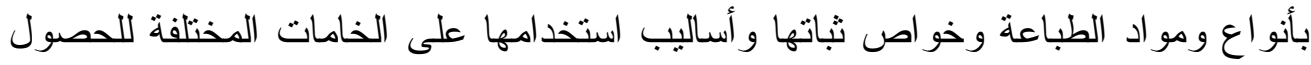

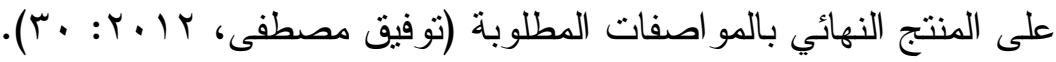


تعرف الخواص الأدائية أيضاً على أنها أنزر الخو اص الطبيعية والميكانيكية المختلفة

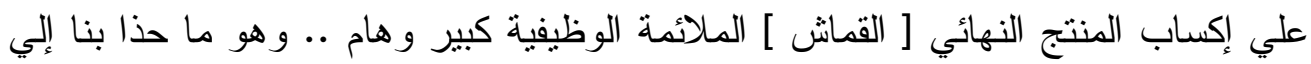

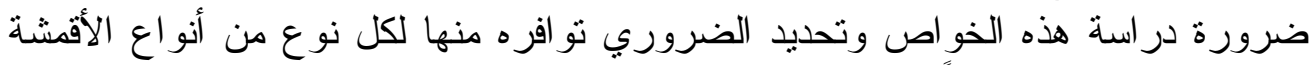
المنتجة تحت الدر اسة تبعاً لنوع استخدامه النهائي (عادل جمال الدين،

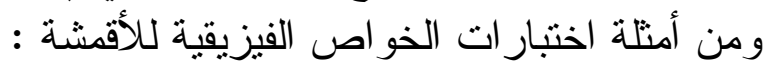

fabric weight

fabric thickness

fabric shrinkage

fabric stiffness

crease recover

air permeability

fabric wettability

flame resistanc e

thermal insulation

fabric drape

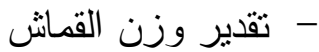
- اختبار سمك القماش ونماش - اختبار انكماش القماش سماك الفماش

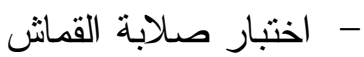
- اختبار الاستعادة من التجعد التمان

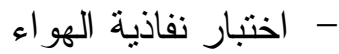

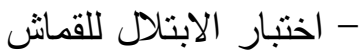

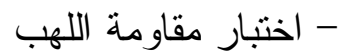

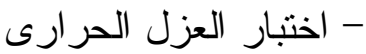
- اختبار انسدال الأقمشة الحزي

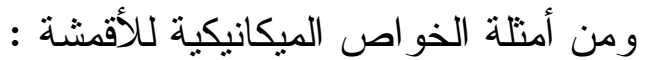
tensile strength and elongation tearing resistance bursting resistance abrasion resistance pilling resistance - اختبار قوة الثد و الاسنطالة - اختبار مقاومة التمزق التمار

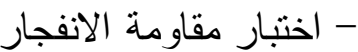

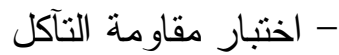

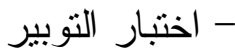

\section{نتائج البحث ومناقشتها:}

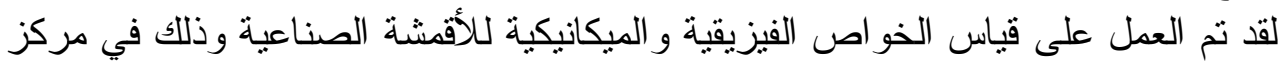
تحليل النسيج وذللك للتحقق من فروض الرسالة وكانت كما يلي: حساب سمك القماش

$$
\text { رقم الكودي للعينة ن/ س / }
$$

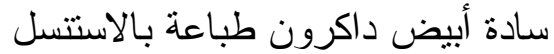

\begin{tabular}{|c|c|c|c|c|c|}
\hline 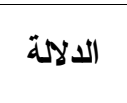 & الررية & قيمة ت & المعياري & الحستوسطي & العينة \\
\hline \multirow{2}{*}{ غير دالة } & \multirow[b]{2}{*}{$\varepsilon$} & \multirow[b]{2}{*}{ - UYV } & $\cdot, \cdots \leqslant \wedge q$ & •, צ৭ & داكرون سادة \\
\hline & & & $\cdot, \ldots \leqslant \wedge q$ & $\cdot, \Gamma \cdot \uparrow$ & مضاف إليه الاستنسل \\
\hline
\end{tabular}

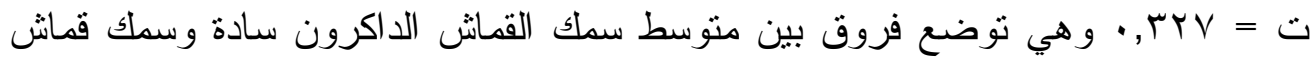

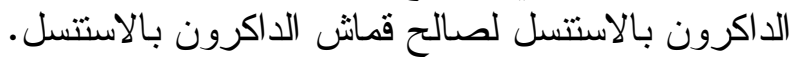


سادة أبيض داكرون طباعة بالبصمة

\begin{tabular}{|c|c|c|c|c|c|}
\hline الدلالة & الدرجة & قيمة & الالحعر في & الحستوسبي & العينة \\
\hline \multirow{2}{*}{ دالة" } & \multirow[b]{2}{*}{$\varepsilon$} & \multirow{2}{*}{$0, v \vee$} & $\cdot, \cdots \leqslant \wedge q$ & .,Y74 & داكرون سادة \\
\hline & & & $\cdot, \cdots \leqslant \wedge q$ & דגז, & مضاف إليه الاستنسل \\
\hline
\end{tabular}

بحساب قيمة ت في الجدول السابق وجد أنها قيمة دالة عند مستوى دلالة 0,VA حيث

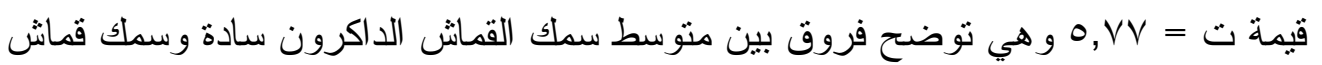

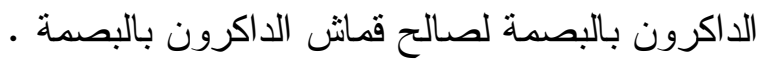

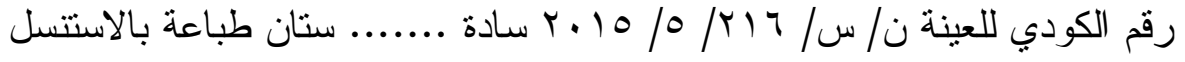

\begin{tabular}{|c|c|c|c|c|c|}
\hline الالالة & الحرجية & 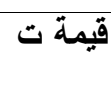 & المعياري & الحستوسبي & العينة \\
\hline \multirow{2}{*}{ غير } & \multirow{2}{*}{$\varepsilon$} & \multirow[t]{2}{*}{$\cdot, 1.9$} & $\cdot, \ldots \leqslant \wedge q$ &., $1 \vee 7$ & ستان سادة \\
\hline & & & $\cdot, \ldots \leqslant \wedge q$ &., $1 \wedge \varepsilon$ & مضاف إليه الاسنتسل \\
\hline
\end{tabular}

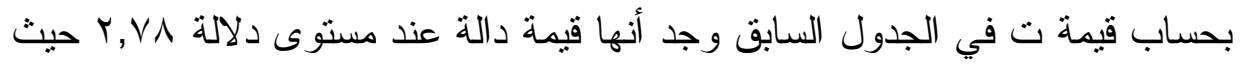

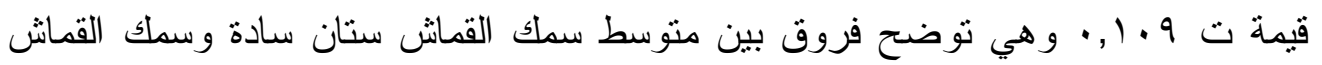

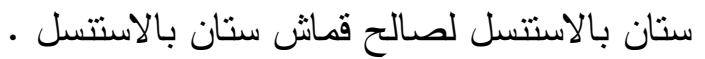
سادة أبيض ستان طبالاسنة • المباعة بالصحة

\begin{tabular}{|c|c|c|c|c|c|}
\hline الالالة & الحرية & قيمة ت ت ق ق ق & الاحر اف المعياري & الحسابي & العينة \\
\hline \multirow[t]{2}{*}{ غير دالة } & \multirow[b]{2}{*}{$\varepsilon$} & \multirow[t]{2}{*}{$1,0 \vee \wedge$} & $\cdot, \ldots \leqslant \wedge q$ &., $1 \vee 7$ & ستان سادة \\
\hline & & & $\cdot, \ldots \leqslant \wedge q$ & דצ & مضاف إليه البصمة \\
\hline
\end{tabular}

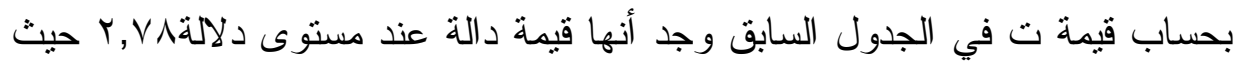
قيمة ت 1,0VA وهي توضح فروق بين متوسط سمك القماش الستان سادة وسمك قماش

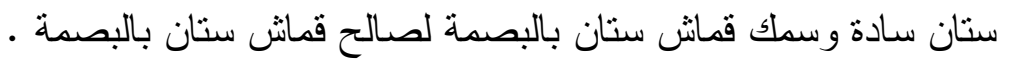

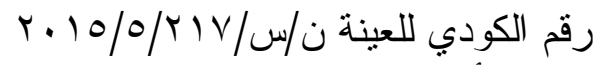
سادة أبيض نايلون طباعة بالاستتسل

\begin{tabular}{|c|c|c|c|c|c|}
\hline الالالة & الحرية & قيمة ت & المعياري & الحسابي & العينة \\
\hline \multirow[b]{2}{*}{ دالة ** } & \multirow[b]{2}{*}{$\varepsilon$} & \multirow[t]{2}{*}{11} & صفر & $\cdot, r, \theta$ & نايلون سادة \\
\hline & & & $\cdot, \ldots \varepsilon$ & $\cdot$, YVY & مضاف إليه الاسنتسل \\
\hline
\end{tabular}

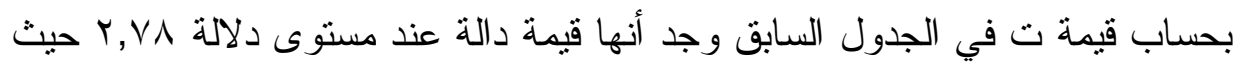
قيمة ت = 11 1 وهي توضح فروق بين منوسط سمك القماش نايلون سادة وسمك قماش دها

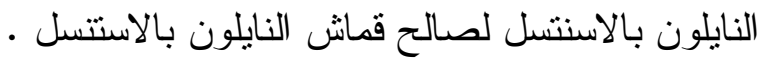




\section{العدد الر ابع يونية ه 1 ــ ( الجزء الثاني )}

سادة أبيض نايلون طباعة بالبصمة

\begin{tabular}{|c|c|c|c|c|c|}
\hline الالالة & الحرجة & قيمة ت & المعياري & الحسابي & العينة \\
\hline \multirow{2}{*}{ دالة "* } & \multirow{2}{*}{$\varepsilon$} & \multirow{2}{*}{$1 ., 7$} & صفر & $\cdot, Y_{O}$ & نايلون سادة \\
\hline & & & $\cdot, \ldots \leqslant \wedge q$ & . YV४ & مضاف إليه البصمة \\
\hline
\end{tabular}

بحساب قيمة ت في الجدول السابق وجد أنها قيمة دالة عن مستوى Y,VA وحيث قيمة ت =7 7, • اوهي توضح فروق بين منتسط سمك قماش النايلون سادة وسمك قماش النايلون بالبصمة لصالح قماش البصمة.

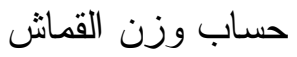

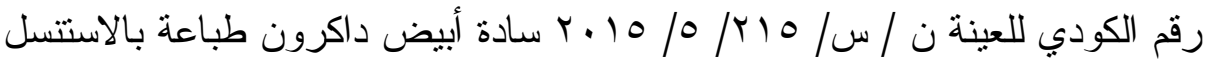

\begin{tabular}{|c|c|c|c|c|c|}
\hline الدلالة & الحرجية & قيمة ت & المعياري & الحستوسبي & العينة \\
\hline \multirow{2}{*}{ دالة : * } & \multirow{2}{*}{$\varepsilon$} & \multirow{2}{*}{$0, \vee \uparrow$} & $r, \wedge \wedge$ & $1 \cdot \varepsilon, r$ & داكرون سادة \\
\hline & & & $r, .40$ & $1.9,9$ & مضاف إليه الاسنتسل \\
\hline
\end{tabular}

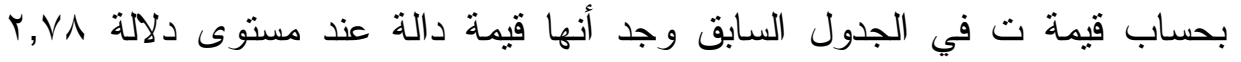
وحيث قيمة ت = 0,V7 و وهي توضح فروق بين متوسط وزن القماش الداكرون سادة ووزن قماش الداكرون بالاستتسل لصالح قماش الداكرون بالاستتسل. سادة أبيض داكرون بالبصمة

\begin{tabular}{|c|c|c|c|c|c|}
\hline اللالالة & الحرية & قيمة & المعياري & الحستابي & العينة \\
\hline \multirow[t]{2}{*}{ دالة "* } & \multirow{2}{*}{$\varepsilon$} & \multirow{2}{*}{$\Delta \wedge, r$} & $r, \wedge \wedge V$ & $1 \cdot \varepsilon, Y$ & داكرون سادة \\
\hline & & & $\cdot, 1 \leqslant$ & $\cdot, Y \vee T$ & مضاف إليه البصمة \\
\hline
\end{tabular}

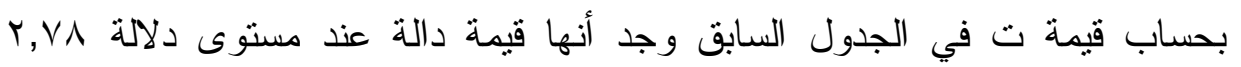

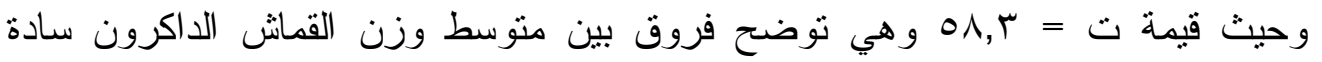
ووزن قماش الداكرون بالبصمة .

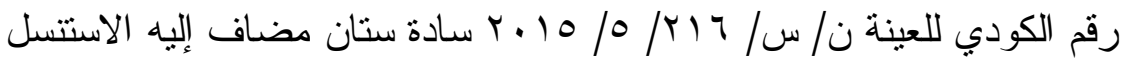

\begin{tabular}{|c|c|c|c|c|c|}
\hline الدلالة & الحرجية & قيمة ت & المعياري & الحستبي & العينة \\
\hline \multirow{2}{*}{ 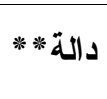 } & \multirow[b]{2}{*}{$\varepsilon$} & \multirow{2}{*}{$1 \%, \cdot v$} & r, 10 & 111,0 & ستان سادة \\
\hline & & & $\varepsilon, Y \otimes \Lambda$ & $119, r$ & مضاف إليه الاستتسل \\
\hline
\end{tabular}

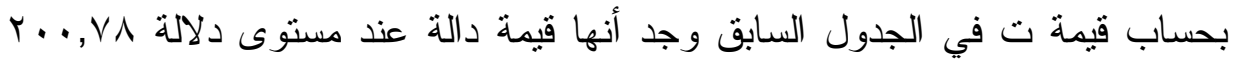

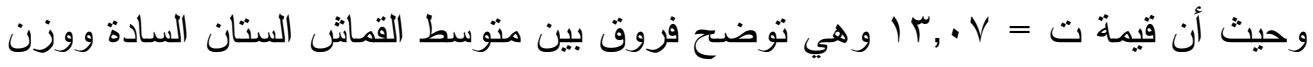
قماش الستان مضاف إليه الاستتسل. 


\section{العدد الر ابع يونية ه 1 ــ ( الجزء الثاني )}

سادة ستان مضاف إليه البصمة

\begin{tabular}{|c|c|c|c|c|c|}
\hline الدلالة & درجة الحرية & قيمة ت & الالمعر افـ & الحستوسطي & العينة \\
\hline \multirow{2}{*}{ دالة * * } & \multirow[b]{2}{*}{$\varepsilon$} & \multirow[b]{2}{*}{$v \bullet, r$} & $r, 70$ & 111,0 & ستان سادة \\
\hline & & & • , & $\mid r \cdot, \cdot \Lambda$ & مضاف الإسنته \\
\hline
\end{tabular}

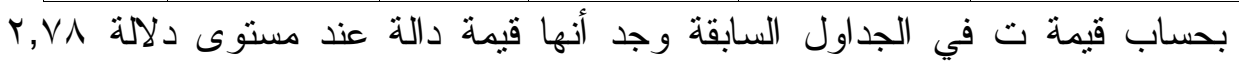
وحيث قيمة ت = r, r و هي توضح فروق بين متوسط وزن القماش الستان السادة ووزن قماش الستان مضاف إليه البصمة.

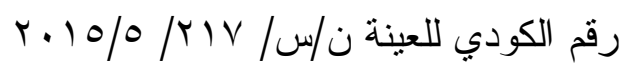

نايلون سادة مضاف إلبه الاستتسل

\begin{tabular}{|c|c|c|c|c|c|}
\hline الدلالة & الحرية & قيمة ت & المعياري اف & الحسابي & العينة \\
\hline \multirow{2}{*}{ دالة ** 2 } & \multirow{2}{*}{$\varepsilon$} & \multirow{2}{*}{ ๑. } & $r, q \cdot r$ & $1,7, r$ & نايلون سادة \\
\hline & & & $\cdot, \mid \leq 1 \leqslant$ & $11 \%, 7$ & مضاف إليه الاسنتسل \\
\hline
\end{tabular}

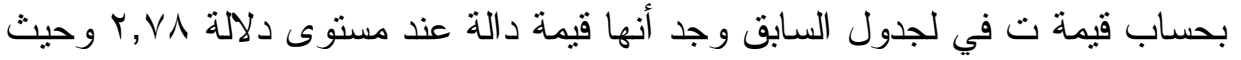

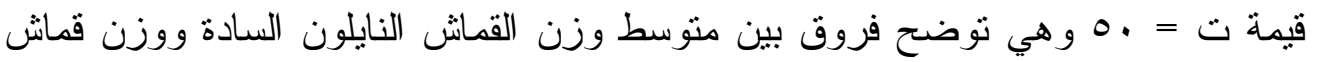
النايلون مضاف إليه الاستتسل.

نايلون سادة مضاف إليه البصمة

\begin{tabular}{|c|c|c|c|c|c|}
\hline الالالة & الحرجية & قيمة ت & الاحر اف المعياري & الحستوسي & العينة \\
\hline \multirow{2}{*}{ دالة ** } & \multirow{2}{*}{$\varepsilon$} & \multirow{2}{*}{ D, } & $r, q, r$ & $1.7, r$ & نايلون سادة \\
\hline & & & $\cdot, \cdot \wedge 9$ & $11 \leq, 9$ & مضاف إليه البصمة \\
\hline
\end{tabular}

بحساب قيمة ت في الجدول السابق وجد أنها قيمة دالة عند مستوى r, VA وحيث قيمة

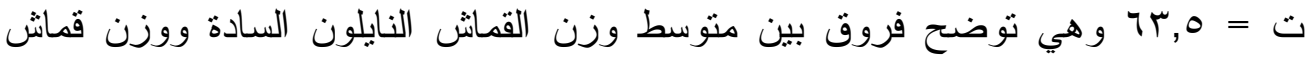
النايلون مضاف إليه البصدة. حساب قوة الثد القاطع في اتجاه السداد.

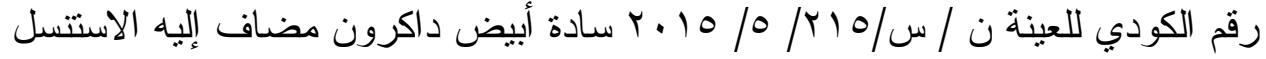

\begin{tabular}{|c|c|c|c|c|c|}
\hline الالالة & درجة الحرية & قيمة ت & المعياري & الحسابي & 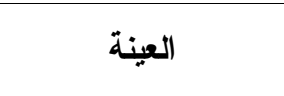 \\
\hline \multirow{2}{*}{ دالة * * } & \multirow{2}{*}{$\varepsilon$} & \multirow{2}{*}{ \&,QYY } & $\cdot, r \mid r$ & $7 \&, 1 Y$ & داكرون سادة \\
\hline & & & r,rV & $90, V$ & مضاف إليه الاسنتسل \\
\hline
\end{tabular}

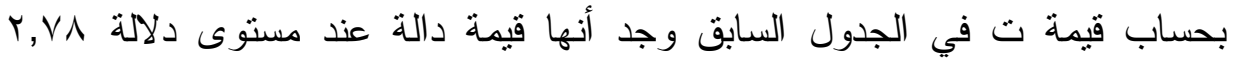

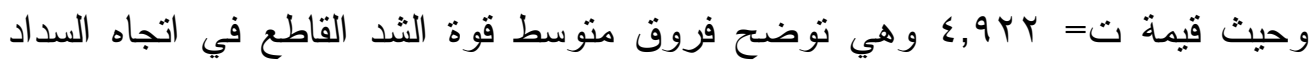

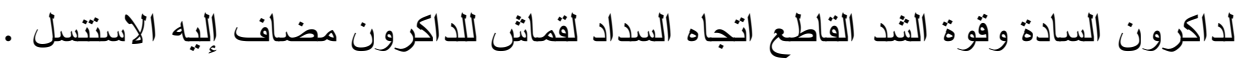


داكرون سادة مضاف إليه البصمة

\begin{tabular}{|c|c|c|c|c|c|}
\hline الدلالة & الحرجية & قيمة ت & المعياري & الحسابي & العينة \\
\hline \multirow{2}{*}{ دالة*** } & \multirow{2}{*}{$\varepsilon$} & \multirow{2}{*}{ r } & $\cdot, Y \backslash r$ & $T \leq, 1 T$ & داكرون سادة \\
\hline & & & . Y & $V \cdot, Y$ & مضاف إليه البصمة \\
\hline
\end{tabular}

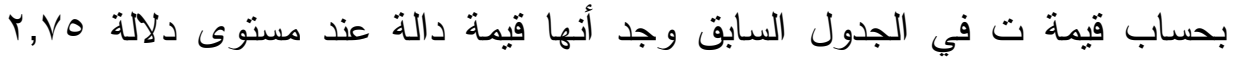
وحيث قيمة ت = ^ • , بr وهي توضح فروق متوسط قوة الثند القاطع قي اتجاه السداد لداكرون السادة وقوة الثد القاطع في اتجاه الالسداد لقماش الداكرون مضاف إليه البصدة .

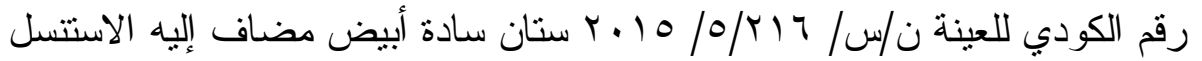

\begin{tabular}{|c|c|c|c|c|c|}
\hline الدلاةة & درجة الحرية & قيمة ت & الالاحيراف & الحسابي & العينة \\
\hline \multirow{2}{*}{ دالة ** } & \multirow{2}{*}{$\varepsilon$} & \multirow{2}{*}{$r, 017$} & 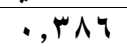 & $\wedge \leqslant,+\wedge$ & ستان سادة \\
\hline & & & $\cdot, V \leqslant \varepsilon$ & $\Lambda \leqslant, q$ & مضاف إليه الاسنتسل \\
\hline
\end{tabular}

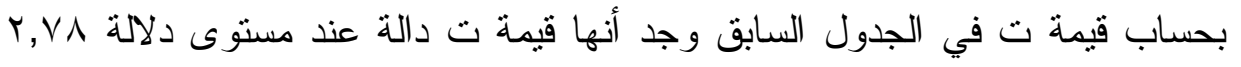
وحيث قيمة ت = r,017 وهي توضح فروق متوسط قوة الثد القاطع في اتجاه السداد الستان السادة وقوة الثد القاطع اتجاه السداد لقماش الستان مضاف إليه الاستتسل . ستان سادة مضاف إلبه البصمة

\begin{tabular}{|c|c|c|c|c|c|}
\hline الدلالة & الحرجية & قيمة ت & المعياري & الحسابي & العينة \\
\hline \multirow{2}{*}{ دالة * * } & \multirow{2}{*}{$\varepsilon$} & \multirow{2}{*}{$\varepsilon \cdot r, q$} &.,$r 97$ & $\Lambda \varepsilon, . \wedge$ & ستان سادة \\
\hline & & & $\cdot, r / 0$ & 91,7 & مضاف إليه البصمة \\
\hline
\end{tabular}

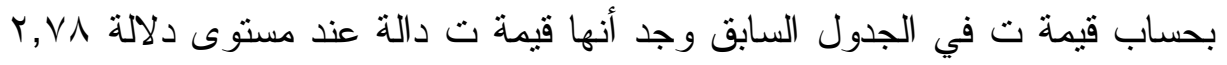

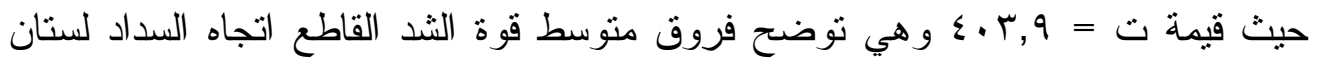

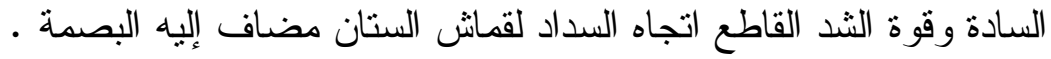

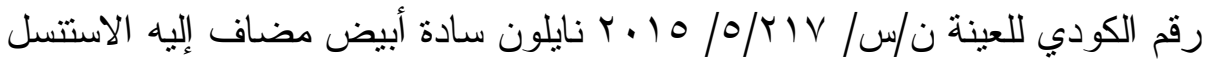

\begin{tabular}{|c|c|c|c|c|c|}
\hline الدلالة & درجة الحرية & قيمة ت & المعياري & الحستبي & العينة \\
\hline \multirow{2}{*}{ دالة * } & \multirow{2}{*}{$\varepsilon$} & \multirow{2}{*}{$v \leqslant, .9$} & $\cdot, Y \leqslant 17$ & 91,79 & نايلون سادة \\
\hline & & & ., YVTV & $1.0,17$ & مضاف إليه الاسنتسل \\
\hline
\end{tabular}

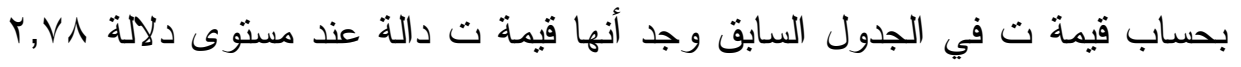
وحيث قيمة ت = 9 . . و وهي توضح فروق متوسط قوة الثند القاطع في اتجاه الالسداد

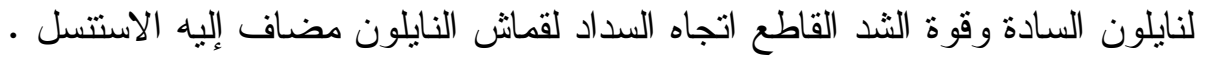


نايلون سادة أبيض مضاف إليه البصمة

\begin{tabular}{|c|c|c|c|c|c|}
\hline الالالة & الحرجة & قيمة ت & الالمعياري اف & المتسابي & العينة \\
\hline \multirow[t]{2}{*}{ دالة * } & \multirow{2}{*}{$\varepsilon$} & \multirow[t]{2}{*}{$\vee q, \vee \varepsilon$} & $\cdot, r \leq 17$ & 91,79 & نايلون سادة \\
\hline & & & • , rrr & $1 \cdot \Lambda, \cdot \varepsilon$ & مضاف إليه الاسنتسل \\
\hline
\end{tabular}

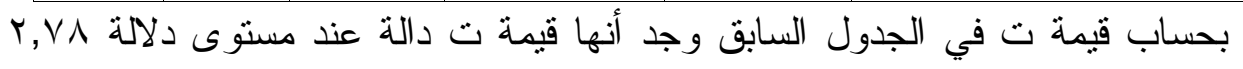

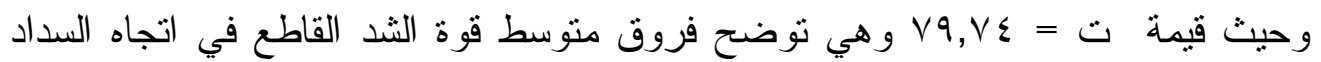

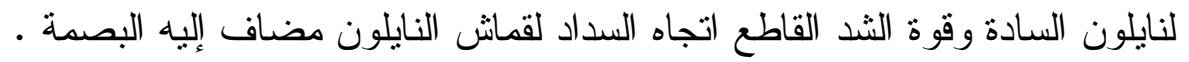

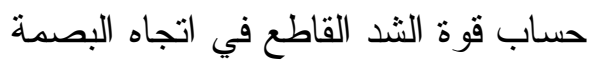

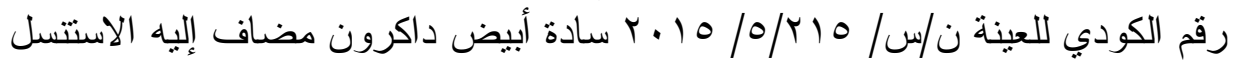

\begin{tabular}{|c|c|c|c|c|c|}
\hline الالالة & الحرية & قيمة ت & الالمعر افي & الحسابي & العينة \\
\hline \multirow[t]{2}{*}{ دالة * } & \multirow{2}{*}{$\varepsilon$} & \multirow[t]{2}{*}{ IT, } & $\cdot, Y V Y$ & $r \theta, \leqslant 0$ & داكرون سادة \\
\hline & & & $\cdot, r q r$ & r^, ४ & مضاف إليه الاسنتسل \\
\hline
\end{tabular}

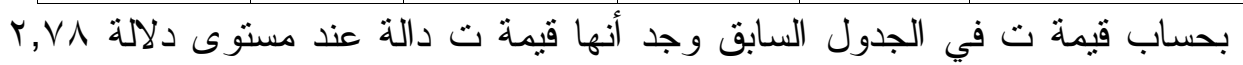

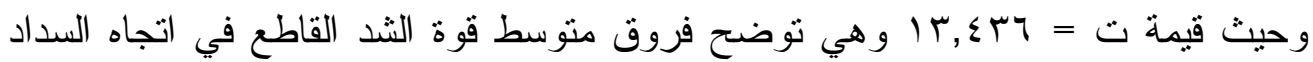

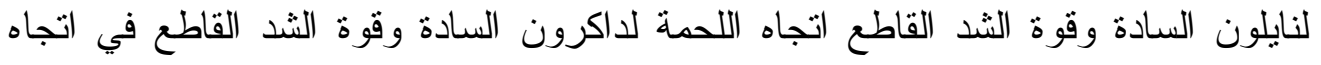
اللحمة لقماش الداكرون مضاف إليه الاستتسل . لإهاه داكرون سادة مضاف إلبه الإن البصمة

\begin{tabular}{|c|c|c|c|c|c|}
\hline الدلالة الة & الررية & قيمة ت & المعياري & الحستبي & العينة - م العة \\
\hline \multirow[t]{2}{*}{ دالة ** } & \multirow[b]{2}{*}{$\varepsilon$} & \multirow[t]{2}{*}{$r \leqslant q, \wedge \leqslant r$} & . YVY & $r 0, \leqslant 0$ & داكرون سادة \\
\hline & & & •, YTI & $\varepsilon r, \varepsilon \mid \varepsilon$ & مضاف إليه البصمة \\
\hline
\end{tabular}

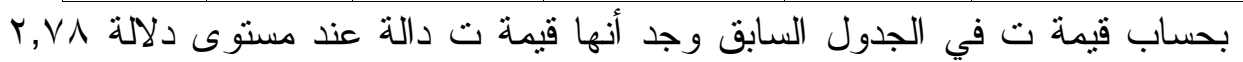

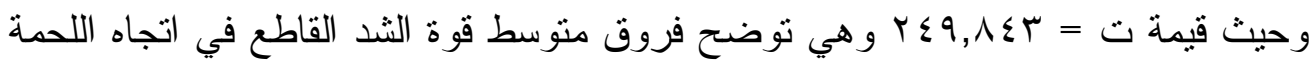

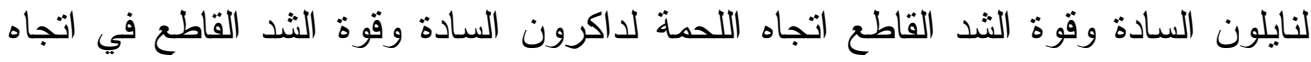
اللحمة لقماش الداكرون مضاف إليه البصمة ـ الباه

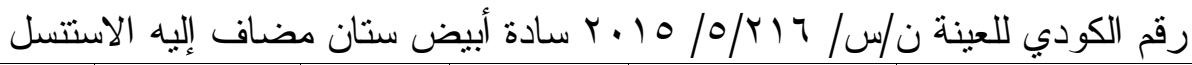

\begin{tabular}{|c|c|c|c|c|c|}
\hline الدلالة & درجة الحرية & قيمة ت & المعياري & المتوسط الحسابي & العينة \\
\hline \multirow{2}{*}{ دالة ** } & \multirow{2}{*}{$\varepsilon$} & \multirow{2}{*}{$1 V, \leqslant 0$} & - & $v_{\bullet, \cdot}$ & ستان سادة \\
\hline & & & $\cdot, r \cdot r \mu$ & $\vee 9, . \leqslant$ & مضاف إليه الاسنتسل \\
\hline
\end{tabular}

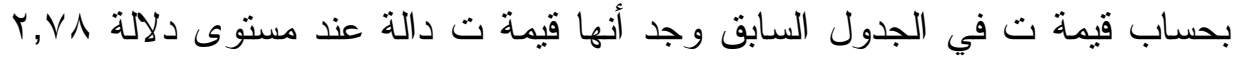

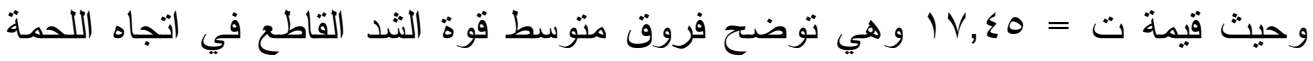

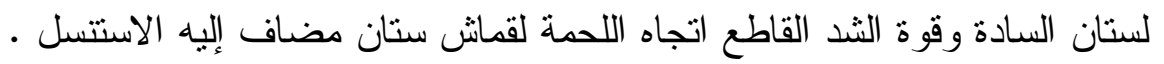


مضاف إلبه البصمة

\begin{tabular}{|c|c|c|c|c|c|}
\hline الدلالة & الرجية & قيمة ت & المعياري & الحسابي & 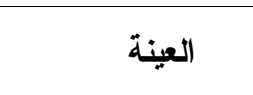 \\
\hline \multirow{2}{*}{ دالة ** } & \multirow{2}{*}{$\varepsilon$} & \multirow{2}{*}{ r r, } & תוז", & $v_{0, .}$ & ستان سادة \\
\hline & & & $\cdot, Y \leq \leqslant 9$ & AY,r & مضاف إليه البصمة \\
\hline
\end{tabular}

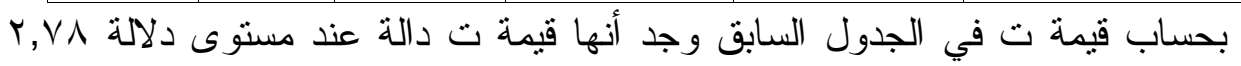

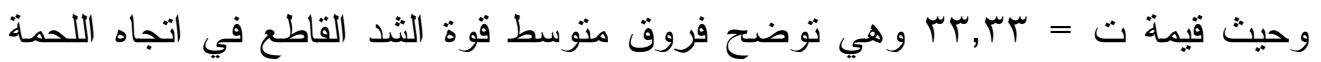

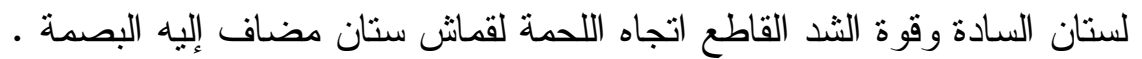

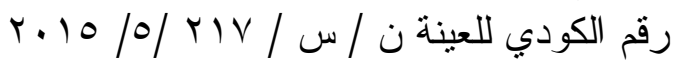
سادة أبيض نايلون مضاف إلبه الاستنسل الإن الاهل

\begin{tabular}{|c|c|c|c|c|c|}
\hline الالالة & الحرية & قيمة ت & الالمعراف & الحستوسطي & العينة \\
\hline \multirow{2}{*}{ دالة * } & \multirow{2}{*}{$\varepsilon$} & \multirow{2}{*}{$174, .9$} & $\cdot, 19$ & $\leqslant \theta, \leqslant \wedge$ & نايلون سادة \\
\hline & & & $\cdot, 1949$ & 70,91 & مضاف إليه الاسنتسل \\
\hline
\end{tabular}

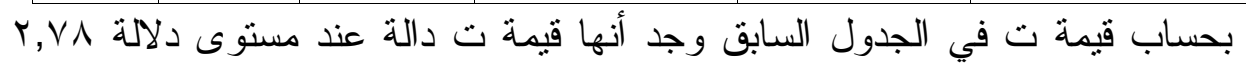

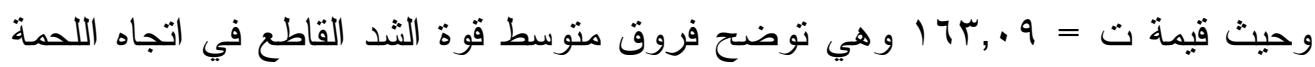

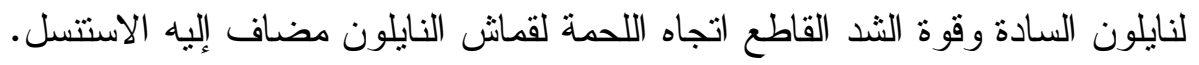
مضاف إلبه البصمة

\begin{tabular}{|c|c|c|c|c|c|}
\hline الدلالة & الحرية & قيمة ت & المعياري & الحستوسي & العينة \\
\hline \multirow{2}{*}{ دالة ** } & \multirow{2}{*}{$\varepsilon$} & \multirow{2}{*}{ IrV, Irq } &., 17 & $\{0, \varepsilon \Lambda$ & نايلون سادة \\
\hline & & & $\cdot, r \leqslant .0$ & $79, \varepsilon$ & مضاف إليه البصمة \\
\hline
\end{tabular}

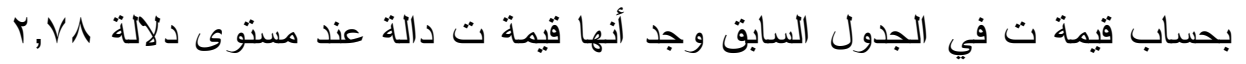

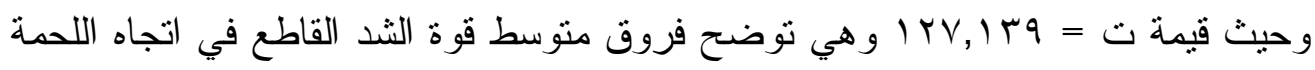
لنايلون السادة وقوة الثد القاطع اتجاه اللحمة لقماش النايلون مضاف توفئ إلبه البصدة.

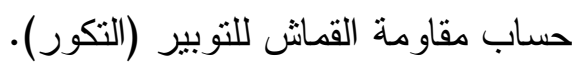

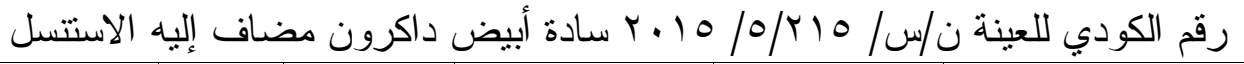

\begin{tabular}{|c|c|c|c|c|c|}
\hline الدلالة & الحرجية & قيمة ت & المعياري & الحسابي & العينة \\
\hline \multirow{2}{*}{ غير دالة } & \multirow{2}{*}{$\varepsilon$} & \multirow{2}{*}{ صفر } & صفر & $r,$. & داكرون سادة \\
\hline & & & صفر & $r, \cdot$ & مضاف إليه الاسنتسل \\
\hline
\end{tabular}

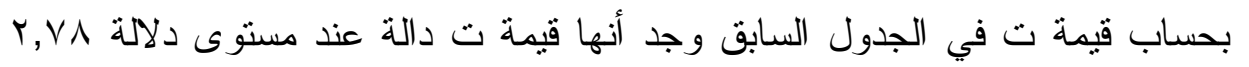
وحيث قيمة ت = صفر وهي توضح فروق منوسط مقاومة القماش للتوبير (التكور)

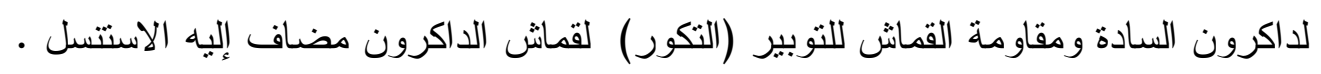


مضاف اليه البصمة

\begin{tabular}{|c|c|c|c|c|c|}
\hline الدلالة & الحرية & قيمة ت & الالمعيار اف & الحستبي & العينة \\
\hline \multirow{2}{*}{ غير دالة } & \multirow{2}{*}{$\varepsilon$} & \multirow[t]{2}{*}{ صفز } & صفز & $r, \cdot$ & داكرون سادة \\
\hline & & & صفز & $r, \cdot$ & مضاف إليه البصمة \\
\hline
\end{tabular}

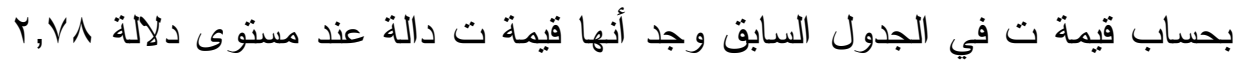
وحيث قيمة ت = صفر وهي توضح فروق منتسط مقاومة القماش للتوبير (التكور)

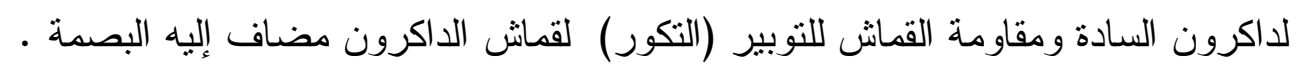

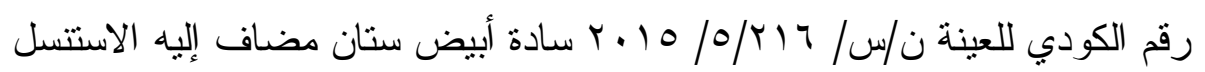

\begin{tabular}{|c|c|c|c|c|c|}
\hline الالالة & الحرجة & قيمة ت & الالحعراري & المتوسط الحسابي & العينة \\
\hline \multirow{2}{*}{ غير دالة } & \multirow{2}{*}{$\varepsilon$} & \multirow{2}{*}{ صفر } & صفز & $\varepsilon, \cdot$ & ستان سـادة \\
\hline & & & صفر & $\varepsilon, \cdot$ & مضاف إليه الاسنتسل \\
\hline
\end{tabular}

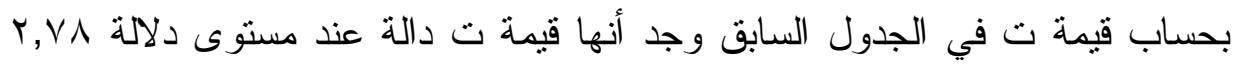
وحيث قيمة ت = صفر وهي توضح فروق منوسط مقاومة القماش للتوبير (التكور ) لستان

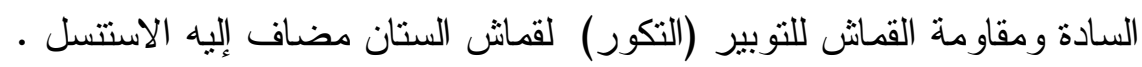
مضاف البه البصمة

\begin{tabular}{|c|c|c|c|c|c|}
\hline الدلالة & الحرية & قيمة ت & المعياري & الحستوسطي & العينة \\
\hline \multirow{2}{*}{ غير دالة } & \multirow{2}{*}{$\varepsilon$} & \multirow{2}{*}{ صفر } & صفر & $\varepsilon$, & ستان سادة \\
\hline & & & صفز & $\varepsilon, \cdot$ & مضاف إليه الاسنتسل \\
\hline
\end{tabular}

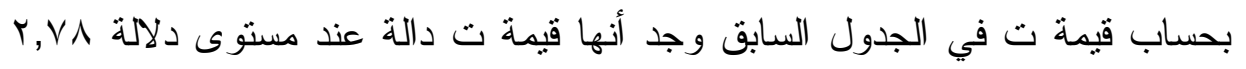
وحيث قيمة ت = صفر وهي توضح فروق منوسط مقاومة القماش للتوبير (التكور ) لستان

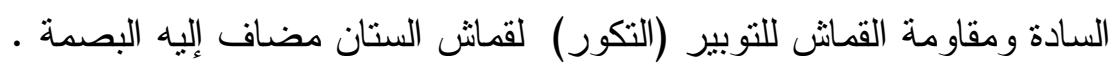

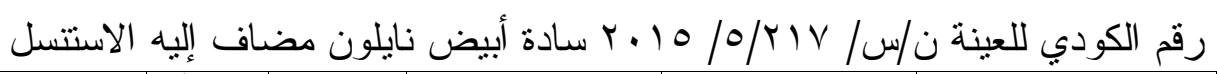

\begin{tabular}{|c|c|c|c|c|c|}
\hline الدلالة & الررجة & قيمة ت & المعياري & الحسابي & العينة \\
\hline \multirow{2}{*}{ غير دالة } & \multirow{2}{*}{$\varepsilon$} & \multirow{2}{*}{ صفز } & صفر & $\varepsilon$, & نايلون سادة \\
\hline & & & صفر & $\varepsilon, \cdot$ & مضاف إليه الاسنتسل \\
\hline
\end{tabular}

بحساب قيمة ت في الجدول السابق وجد أنها قيمة ت دالة عند مستوى دلالة الابلة وحيث قيمة ت = صفر وهي توضح فروق منوسط مقاومة القماش للتوبير (التكور) لنايلون

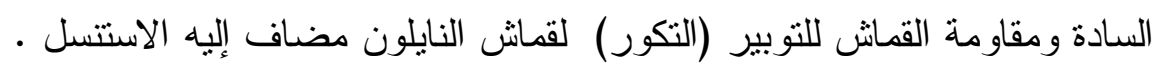


مضاف إليه البصمة

\begin{tabular}{|c|c|c|c|c|c|}
\hline الالالة & الررية & قيمة ت & المعياري & المتوسط الحسابي & العينة \\
\hline \multirow{2}{*}{ غير } & \multirow{2}{*}{$\varepsilon$} & \multirow{2}{*}{ صفر } & صفر & $\varepsilon, \cdot$ & نايلون سادة \\
\hline & & & صفر & $\varepsilon$, & مضاف إليه الاسنتسل \\
\hline
\end{tabular}

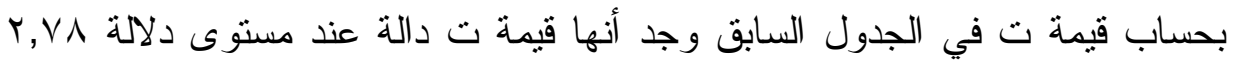
وحيث قيمة ت = صفر وهي توضح فروق منتسط مقاومة القماش للتوبير (التكور) لنايلون

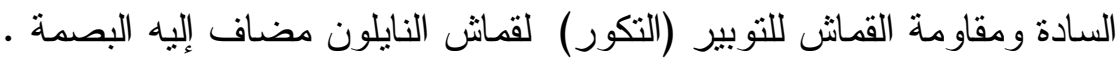

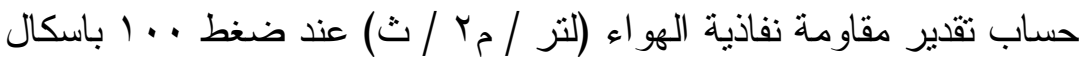
رقم الكودي للعينة ن/س/

\begin{tabular}{|c|c|c|c|c|c|}
\hline الدلالة & الدرجة & قيمة ت & الالحيرافي & المتوسط الحسابي & العينة - ب العة \\
\hline \multirow{2}{*}{ 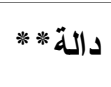 } & \multirow{2}{*}{$\varepsilon$} & \multirow{2}{*}{ r, $\vee \wedge q$} & $r ., 119$ & 9.7 & داكرون سادة \\
\hline & & & $r \theta, \leqslant 1 \leqslant$ & $\Lambda \leqslant q, Y$ & مضاف إليه الاسنتسل \\
\hline
\end{tabular}

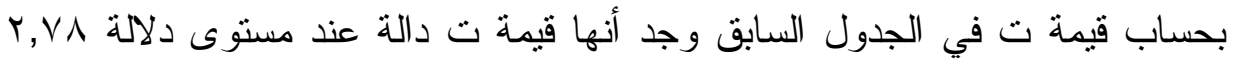
وحيث قيمة ت = r,VA9 و هي توضح فروق منوسط مقاومة نفاذية الهو اء لداكرون السادة

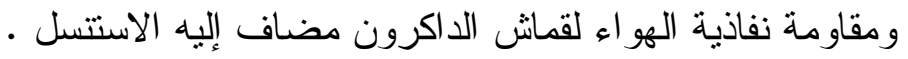
مضاف البه البصمة - 20 - ماف

\begin{tabular}{|c|c|c|c|c|c|}
\hline الدلالة & الحرجية & قيمة ت & المعياري & المتوسط الحسابي & 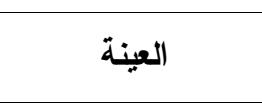 \\
\hline \multirow{2}{*}{ غير دالة } & \multirow{2}{*}{$\varepsilon$} & \multirow{2}{*}{$r, .0 \leqslant$} & $r \cdot, 119$ & 9.7 & داكرون سادة \\
\hline & & & YI,YYA & $\Lambda \Upsilon q, \wedge$ & مضاف إليه البصمة \\
\hline
\end{tabular}

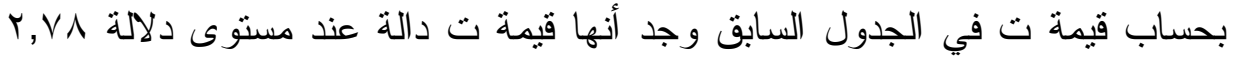
وحيث قيمة ت = ؟ ه. r وهي توضح فروق متوسط مقاومة نفاذية الهو اء لداكرون السادة

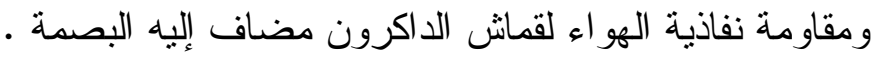

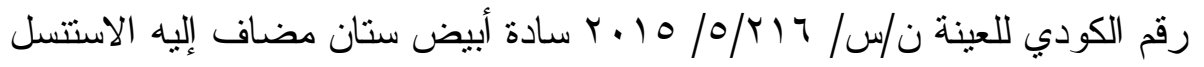

\begin{tabular}{|c|c|c|c|c|c|}
\hline الالالة & الحرية & قيمة ت & المعياري & الحستابي & العينة \\
\hline \multirow{2}{*}{ 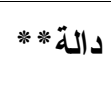 } & \multirow{2}{*}{$\varepsilon$} & \multirow{2}{*}{$r, \ldots \varepsilon$} & $v, \ldots \wedge$ & $00, \ldots$ & ستان سادة \\
\hline & & & V,QYr & rq, $1 \leqslant$ & مضاف إليه الاسنتسل \\
\hline
\end{tabular}

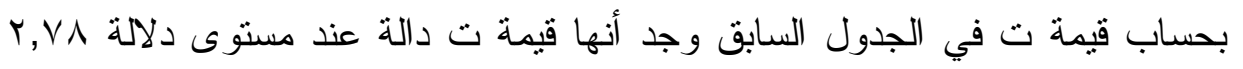
وحيث قيمة ت = ع .., ب وهي توضح فروق متوسط مقاومة نفاذية الهواء لستان السادة

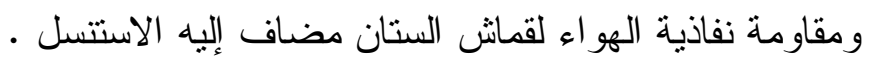


مضاف اليه البصمة

\begin{tabular}{|c|c|c|c|c|c|}
\hline الالالة & الحرية & قيمة ت & الالمعراري & المستوسطي & العينة \\
\hline \multirow{2}{*}{ دالة * } & \multirow{2}{*}{$\varepsilon$} & \multirow{2}{*}{$\vee, \wedge \div \vee$} & $\ddot{v}, \ldots \wedge$ & $00, \cdot \varepsilon$ & ستان سادة \\
\hline & & & $r, Y \wedge$ & $r \leqslant, T$ & مضاف إليه البصمة \\
\hline
\end{tabular}

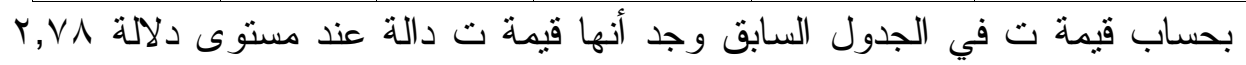

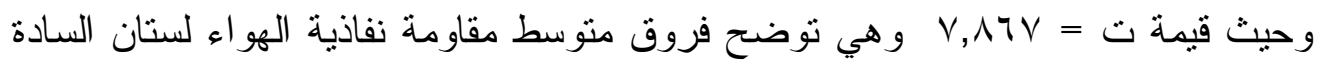

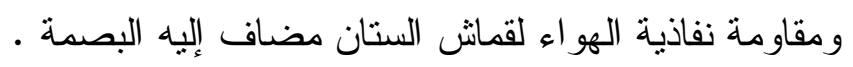

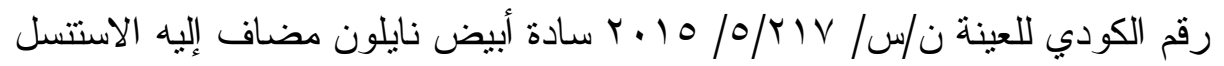

\begin{tabular}{|c|c|c|c|c|c|}
\hline الدلالة & الحرجية & قيمة ت & المعياري & المتوسط الحسابي & العينة \\
\hline \multirow{2}{*}{ دالة * } & \multirow{2}{*}{$\varepsilon$} & \multirow{2}{*}{$\Lambda, r Y}$. & $Y \Lambda, Y Y \varepsilon$ & $\leqslant 1 \cdot, \cdot$ & نايلون سادة \\
\hline & & & $\wedge, \Upsilon 11$ & $r \wedge V, Y$ & مضاف إليه الاسنتسل \\
\hline
\end{tabular}

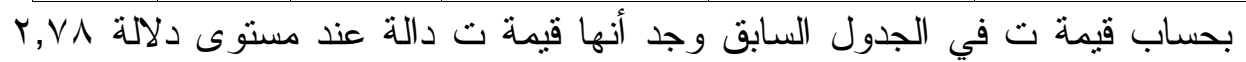

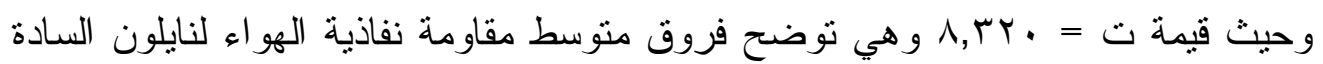

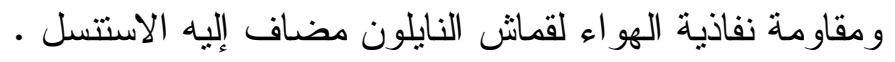
مضاف اليه البصمة

\begin{tabular}{|c|c|c|c|c|c|}
\hline الدلالة & الدرجية & قيمة ت & المعياري & المتوسط الحسابي & 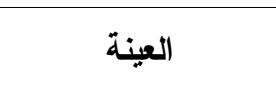 \\
\hline \multirow{2}{*}{ 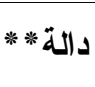 } & \multirow{2}{*}{$\varepsilon$} & \multirow{2}{*}{$0,1 \leqslant 9$} & YA,YT\& & $\leqslant 1 \cdot$, & نايلون سادة \\
\hline & & & \& & YVף,Y & مضاف إليه الاسنتسل \\
\hline
\end{tabular}

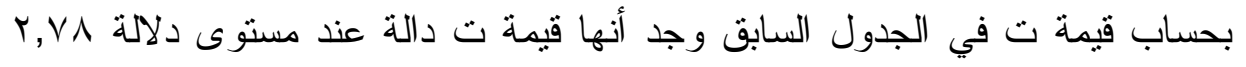

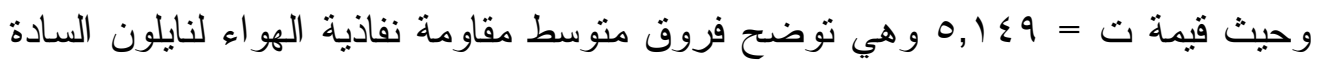

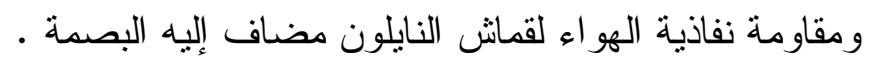
حساب الفروق بين الاستتسل و البصمة داكرون ستان نايلون

حساب سمك القماش

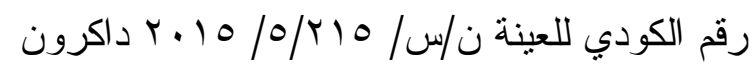

داكرون سادة مضاف إليه الاستتسل و البصمة البهمة

\begin{tabular}{|c|c|c|c|c|c|}
\hline الدلالة & الحرجية & قَّمة & الالحعراف & الحستابي & العينة \\
\hline \multirow{2}{*}{ 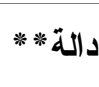 } & \multirow{2}{*}{$\varepsilon$} & \multirow{2}{*}{$\bullet, \vee \wedge$} & $\cdot, \ldots \leqslant \wedge q$ & $\cdot, \mu \cdot \uparrow$ & داكرون مضاف اليه الاستتسل \\
\hline & & & $\cdot, \ldots \leqslant \wedge q$ & $\cdot, Y \wedge \uparrow$ & مضاف إلبه البصمة \\
\hline
\end{tabular}

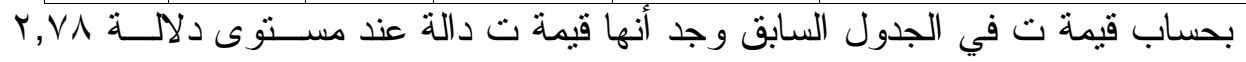

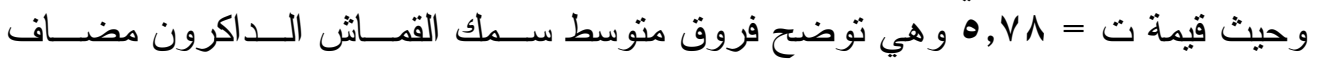

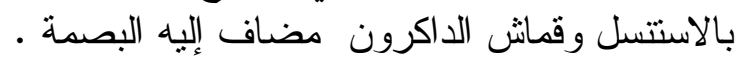




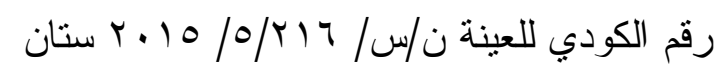

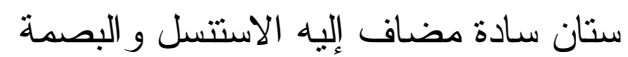

\begin{tabular}{|c|c|c|c|c|c|}
\hline الدلالة & الرجية & ق قيمة ت & المعياري & الحستبي & العينة \\
\hline \multirow{2}{*}{ داثير } & \multirow{2}{*}{$\varepsilon$} & \multirow{2}{*}{ r,Yio } & $\cdot, \cdots \leqslant \wedge q$ & $\cdot, 11 \varepsilon$ & ستان مضاف اليه الاستتسل \\
\hline & & & $\cdot, \ldots \leqslant \wedge q$ & $\cdot$, Y ४ & مضاف إليه البصمة \\
\hline
\end{tabular}

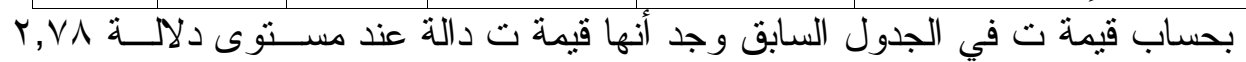

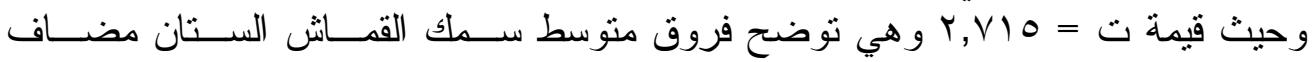

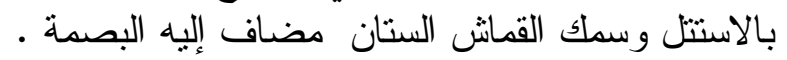

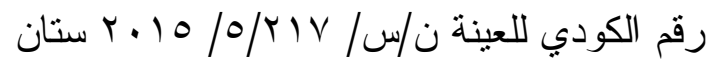

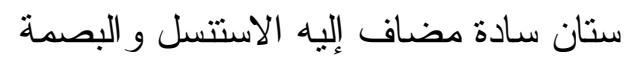

\begin{tabular}{|c|c|c|c|c|c|}
\hline الدلالة - مالة & الحرجية & قيمة ت & المعياري & الحستابي & العينة \\
\hline \multirow{2}{*}{ غية } & \multirow{2}{*}{$\varepsilon$} & \multirow{2}{*}{1, Y } & $\cdot, \ldots \varepsilon$ & $\cdot, Y V Y$ & نايلون مضاف اليه الاستتسل \\
\hline & & & $\cdot, \ldots \leqslant \wedge q$ & $\cdot$ •, YV\ & مضاف إليه البصمة \\
\hline
\end{tabular}

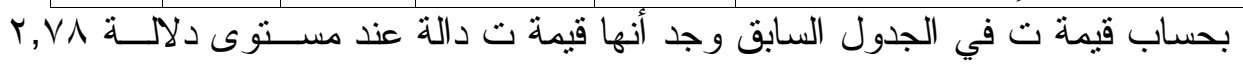

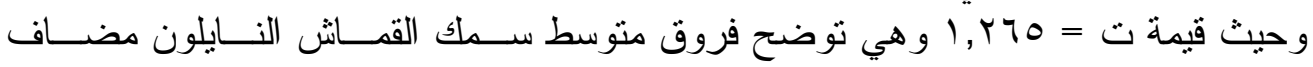

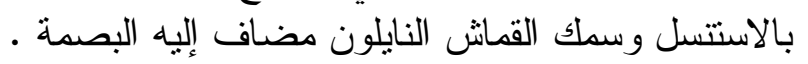

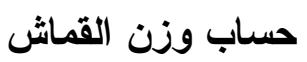

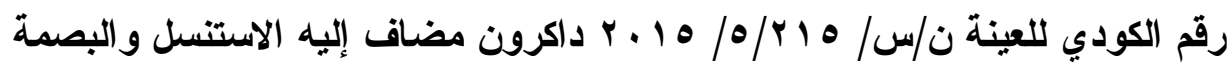

\begin{tabular}{|c|c|c|c|c|c|}
\hline الدلالة & الحرجة & 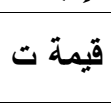 & المعياري & الحستبي & العينة \\
\hline \multirow{2}{*}{ دالة ** } & \multirow{2}{*}{$\varepsilon$} & \multirow{2}{*}{$9, Y \mu V$} & $Y, .70$ & $1.7,9$ & داكرون مضاف اليه الاستتسل \\
\hline & & & $\cdot, 1 \leqslant$ & $1 \cdot v, v$ & مضاف إليه البصمة \\
\hline
\end{tabular}

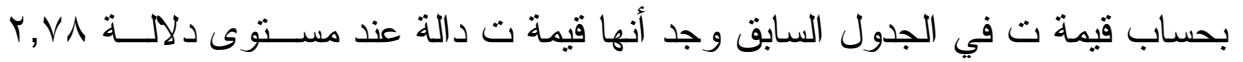

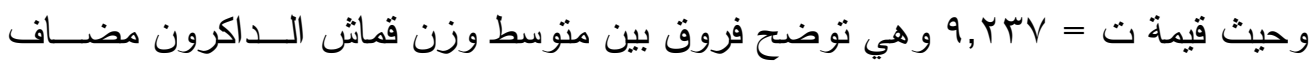

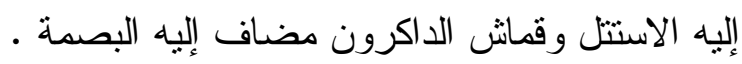

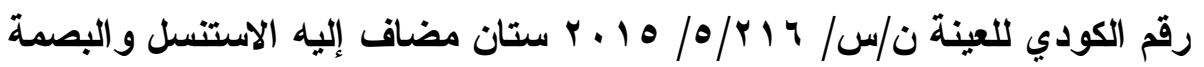

\begin{tabular}{|c|c|c|c|c|c|}
\hline الدلالة & الحرية & قيمة ت & المعياري & الحستوسي & العينة \\
\hline \multirow{2}{*}{ دالة ** } & \multirow{2}{*}{$\varepsilon$} & \multirow{2}{*}{ Or,Vr } & $\varepsilon, Y \circ \Lambda$ & $\overline{i l r} r$ & ستان مضاف اليه الاستنسل \\
\hline & & & $\cdot$, Y IT & $1 Y \cdot, \cdot 1$ & مضاف إليه البصمة \\
\hline
\end{tabular}

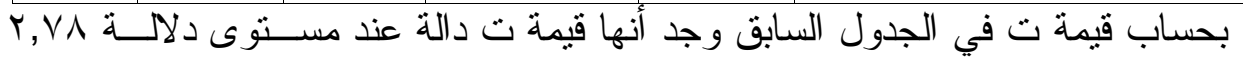

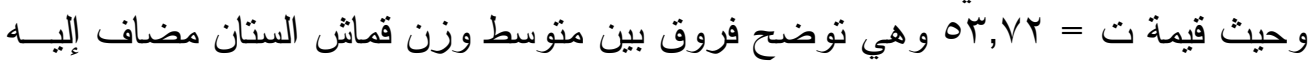

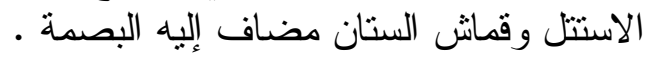




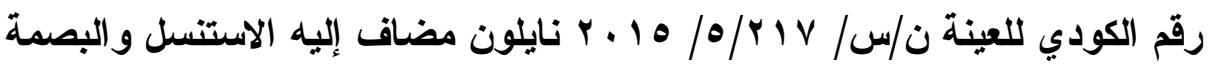

\begin{tabular}{|c|c|c|c|c|c|}
\hline 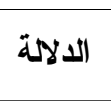 & الحرجية & قيمة ت & المعياري & الحسابي & العينة \\
\hline \multirow{2}{*}{ دالة ** } & \multirow{2}{*}{$\varepsilon$} & \multirow{2}{*}{17,190} &., $1 \leqslant 1 \leqslant$ & $11+, 4$ & نايلون مضاف اليه الاستتسل \\
\hline & & & $\cdot, \cdot \wedge 9 \leqslant$ & $11 \leqslant, 9$ & مضاف إليه البصمة \\
\hline
\end{tabular}

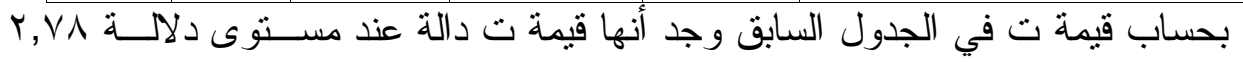

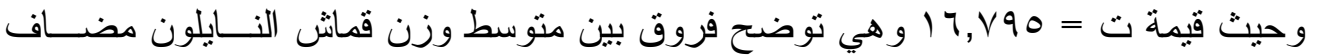

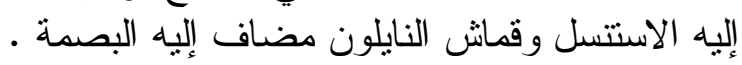

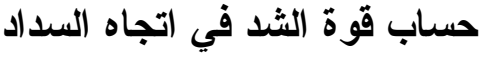

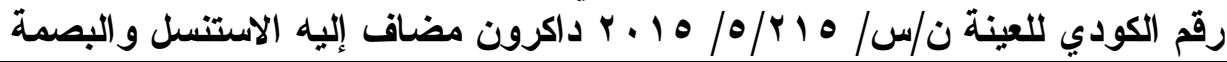

\begin{tabular}{|c|c|c|c|c|c|}
\hline الدلالة & الحرية & قيمة ت & المعياري & الحستوسطي & العينة \\
\hline \multirow{2}{*}{ دالة * * } & \multirow{2}{*}{$\varepsilon$} & \multirow{2}{*}{ אוד, 14ו } & $r, r V$ & $70, \mathrm{~V}$ & داكرون مضاف اليه الاستنسل \\
\hline & & & 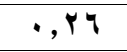 & $V \cdot, r$ & مضاف إليه البصمة \\
\hline
\end{tabular}

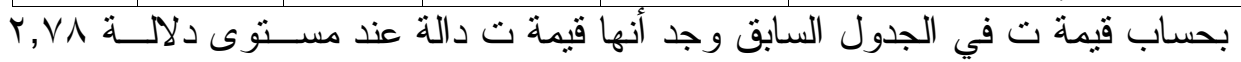

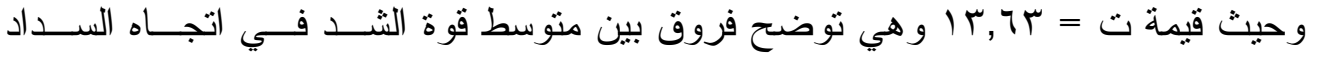

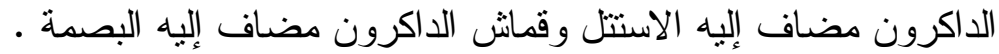

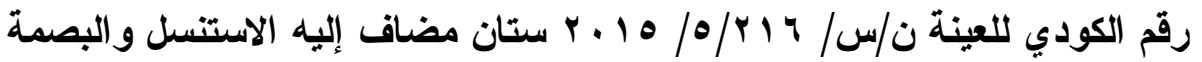

\begin{tabular}{|c|c|c|c|c|c|}
\hline الدلالة & الدرجية & قيمة ت & المعياري & الحستبابي & العينة \\
\hline \multirow{2}{*}{ 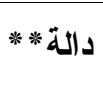 } & \multirow{2}{*}{$\varepsilon$} & \multirow{2}{*}{$r 9,7$} & $\cdot, r \leq \leqslant$ & $\wedge \leqslant, q$ & ستان مضاف اليه الاستتسل \\
\hline & & & $\cdot, r / 0$ & $91, r 4$ & مضاف إليه البصمة \\
\hline
\end{tabular}

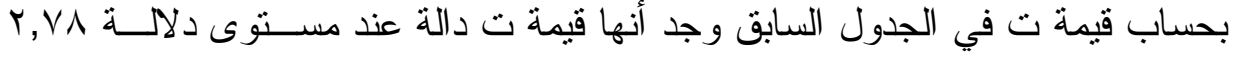

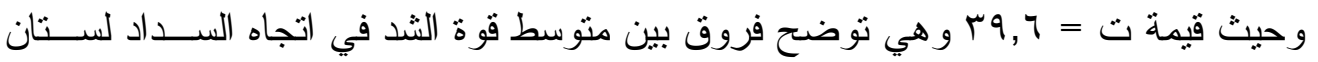

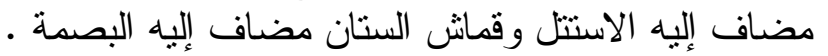

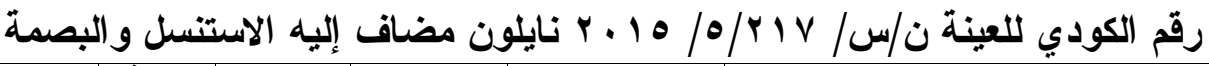

\begin{tabular}{|c|c|c|c|c|c|}
\hline الدلالة - مالة & الحرجة & 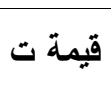 & المعياري & الحستابي & العينة \\
\hline \multirow{2}{*}{ 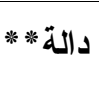 } & \multirow{2}{*}{$\varepsilon$} & \multirow{2}{*}{$1 \%, \xi$} &.,$Y V Y V$ & $1.0,17$ & نايلون مضاف اليه الاستتسل \\
\hline & & & •, MTY & $1 \cdot \Lambda, \cdot \varepsilon$ & مضاف إليه البصمة \\
\hline
\end{tabular}

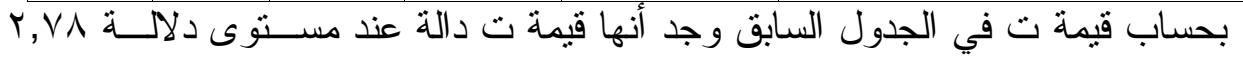

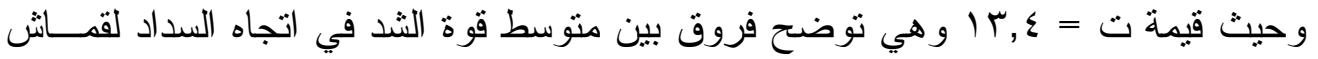

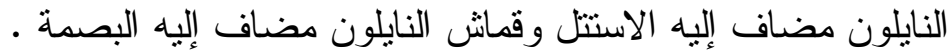

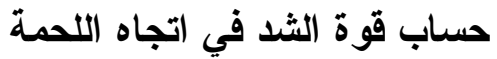

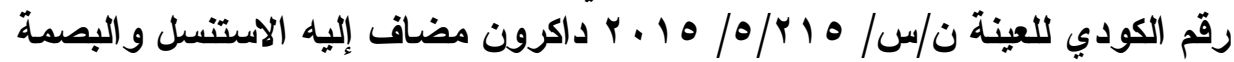

\begin{tabular}{|c|c|c|c|c|c|}
\hline الدلالة & الحرجية & قيمة ت & المعياري & المتوسط الحسابي & العينة \\
\hline \multirow{2}{*}{ 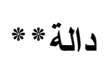 } & \multirow{2}{*}{$\varepsilon$} & \multirow{2}{*}{$r \cdot, \wedge 0$} & . rar & $r \Lambda, \uparrow 4$ & داكرون مضاف اليه الاستتسل \\
\hline & & & . YTI & $\leqslant \Psi, \leqslant) \leqslant$ & مضاف إليه البصمة \\
\hline
\end{tabular}




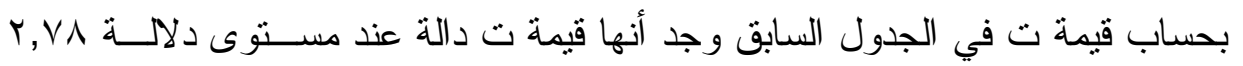

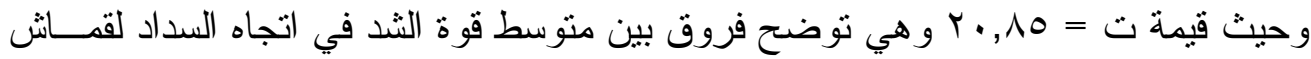
الداكرون مضاف إليه الاستتل وقماش الداكرون مضاف فروف بـ إليه البصمة .

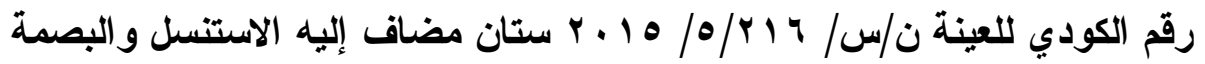

\begin{tabular}{|c|c|c|c|c|c|}
\hline الدلالة & الدرجة & 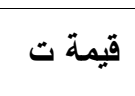 & المعياري & الحستبي & العينة \\
\hline \multirow{2}{*}{ 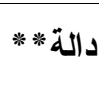 } & \multirow{2}{*}{$\varepsilon$} & \multirow{2}{*}{$I V, Y V A$} & $\cdot, r \cdot Y r$ & $\sqrt{9, \cdot} \leqslant$ & ستان مضاف اليه الاستتسل \\
\hline & & & $\cdot, Y \backslash 19$ & Ar,r & مضاف إليه البصمة \\
\hline
\end{tabular}

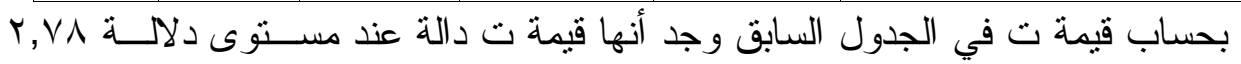

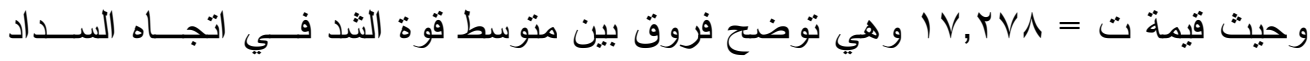

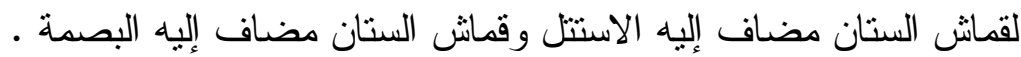

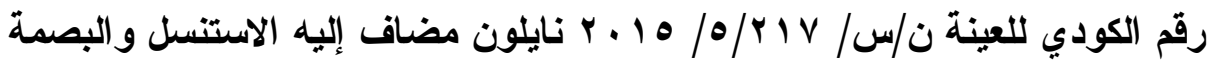

\begin{tabular}{|c|c|c|c|c|c|}
\hline الدلالة & الدرجة & 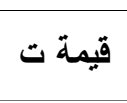 & المعياري & الحسابي & 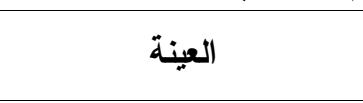 \\
\hline \multirow{2}{*}{ دالة ** } & \multirow{2}{*}{$\varepsilon$} & \multirow{2}{*}{ IV, $\leqslant \Delta Y$} &., 1949 & 90,91 & نايلون مضاف اليه الاستنسل \\
\hline & & & $\cdot, r \leqslant .0$ & 79,8 & مضاف إليه البصمة \\
\hline
\end{tabular}

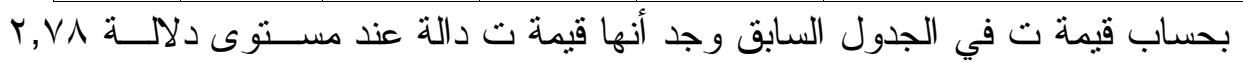

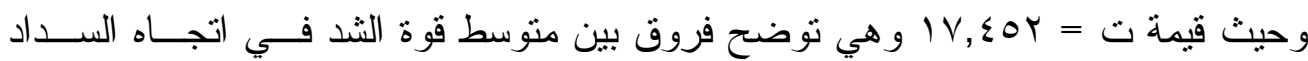

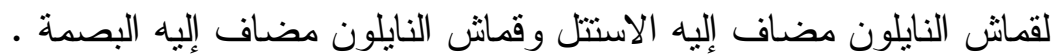

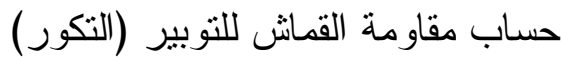

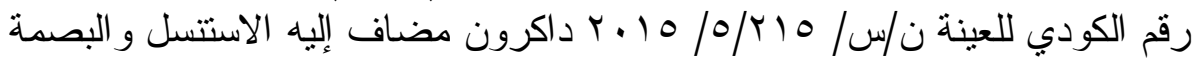

\begin{tabular}{|c|c|c|c|c|c|}
\hline 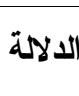 & الدرجية & قيمة ت & الالحعراف & الحستابي & العينة \\
\hline \multirow{2}{*}{ دالةير } & \multirow{2}{*}{$\varepsilon$} & \multirow{2}{*}{ صفر } & صفز & $r, \cdot$ & داكرون مضاف اليه الاستتسل \\
\hline & & & صفر & $r, \cdot$ & مضاف إليه البصمة \\
\hline
\end{tabular}

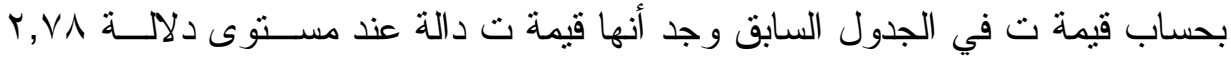

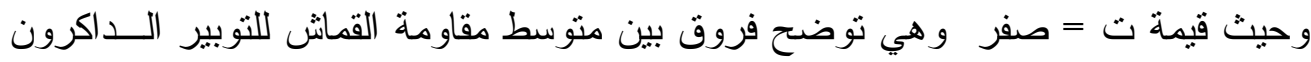

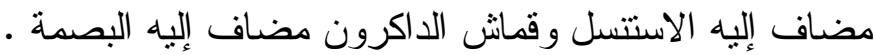

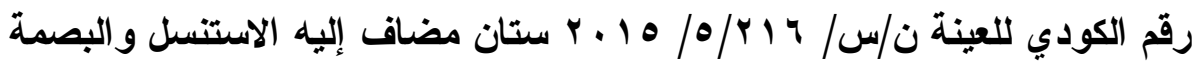

\begin{tabular}{|c|c|c|c|c|c|}
\hline الدلالة & الدرجة & قيمة ت & الالحعياري & الحستوسي & العينة \\
\hline \multirow{2}{*}{ دالةير } & \multirow{2}{*}{$\varepsilon$} & \multirow{2}{*}{ صفز } & صفر & $\varepsilon$, & ستان مضاف اليه الاستتسل \\
\hline & & & صفر & $\varepsilon$, & مضاف إليه البصمة \\
\hline
\end{tabular}

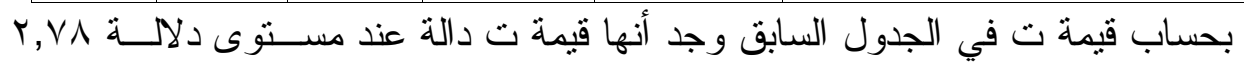

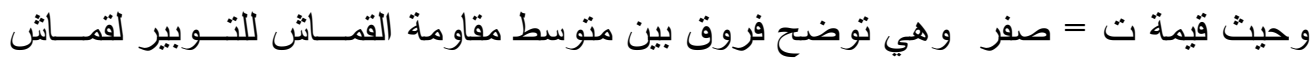

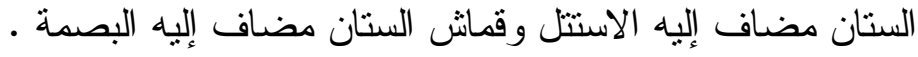


العدد الر ابع يونية 1 ا ـ r ( الجزء الثاني )

المجلة العلمية لكلية التربية النوعية

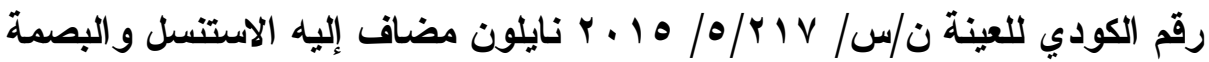

\begin{tabular}{|c|c|c|c|c|c|}
\hline الدلالة & الحرجة & قيمة ت & الالمعرار اف & المستوسطي & العينة \\
\hline 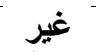 & & ف & صفز & $\varepsilon$, & نايلون مضاف اليه الاستتسل \\
\hline د الة & $\varepsilon$ & صعر & صفر & $\varepsilon$, & مضاف إليه البصمة \\
\hline
\end{tabular}

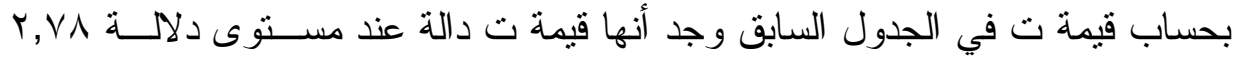
وحيث قيمة ت = صفر وهي توضح فروق بين منوسط مقاومة القماش للتـوبير لنـايلون

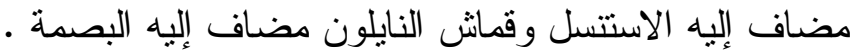

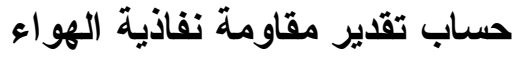

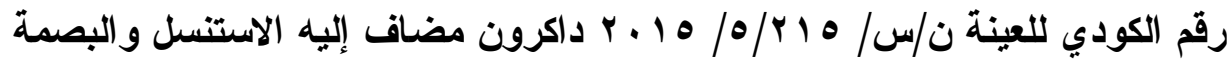

\begin{tabular}{|c|c|c|c|c|c|}
\hline الدلاهة & الحرية & قيمة ت & الآمعراري & الحستوسطي & العينة \\
\hline \multirow{2}{*}{ غير دالة } & & \multirow{2}{*}{$\cdot, Y 70$} & ro, \&1 & $\Lambda \leq 9, r$ & داكرون مضاف اليه الاستنسل \\
\hline & & & YI, YYA & $\wedge r q, \Lambda$ & مضاف إلبه البصمةة \\
\hline
\end{tabular}

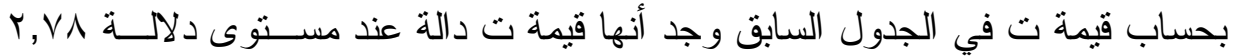

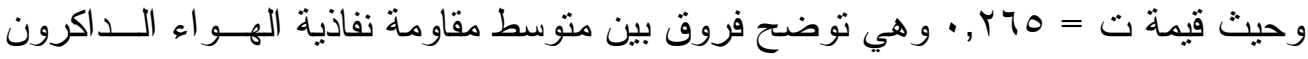

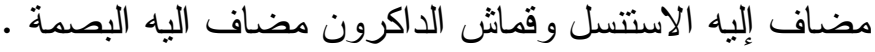

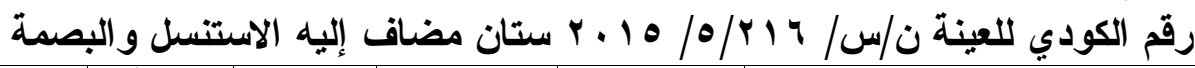

\begin{tabular}{|c|c|c|c|c|c|}
\hline الدالاة & الحرجية & قيمة ت & الالمعيار افي & الحستبي المتوسط & العينة الع \\
\hline \multirow[t]{2}{*}{ ل دالة * * } & \multirow[b]{2}{*}{$\varepsilon$} & \multirow{2}{*}{$r, r \wedge v$} & $\mathrm{~V}, 9 \mathrm{rr}$ & $r q, 1 \leq$ & ستان مضاف اليه الاستتسل \\
\hline & & & $r, r \wedge$ & $r \leqslant, Y$ & مضاف إليه البصمة \\
\hline
\end{tabular}

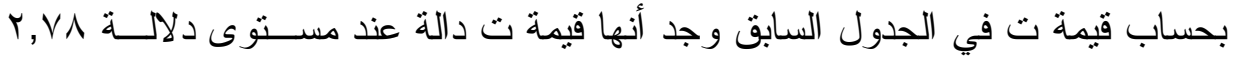

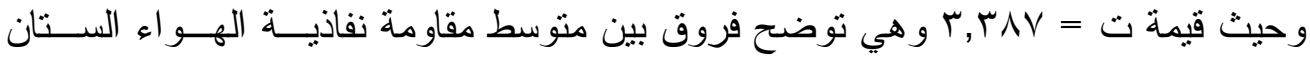

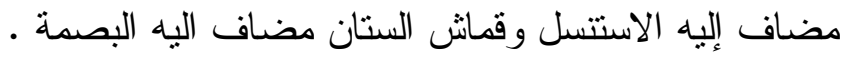

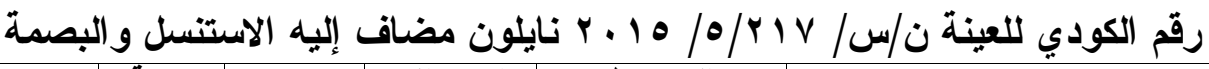

\begin{tabular}{|c|c|c|c|c|c|}
\hline الدلالة & الحرية & قيمة ت & المعياري & المتوسابي & 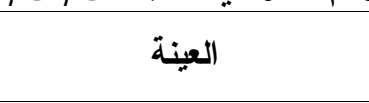 \\
\hline \multirow{2}{*}{ غالة } & \multirow[b]{2}{*}{$\varepsilon$} & \multirow{2}{*}{$\cdot, \leqslant 9 \leqslant$} & $\wedge, 711$ & $r \wedge \vee, r$ & نايلون مضاف اليه الاستتسل \\
\hline & & & $\{\Psi, Y Y V$ & $Y V Y, Y$ & مضاف إليه البصمة \\
\hline
\end{tabular}

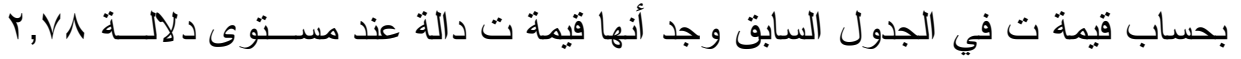

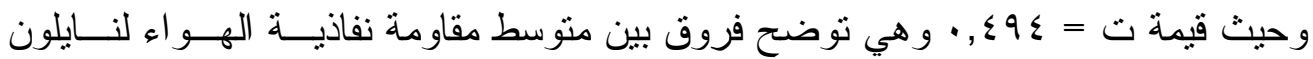

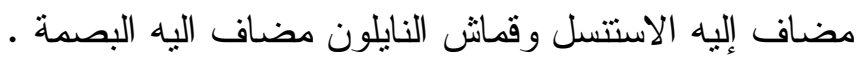
يوصي البحث:

ا ـ زيادة الدر اسات الخاصة بأنو اع الطباعة المختلفة مع أقمشة صناعية مختلفة.

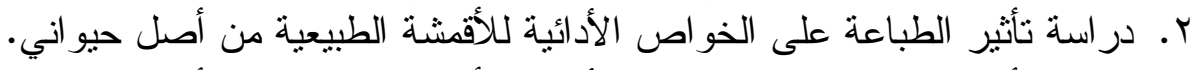
r. در اسة تأثثر الطباعة على الخو اص الأدائية للأقمشة الطبيعية من أصل نباتي. 
" :

رنا محمد فودة

متنوعة من التطريز و الطباعة لعمل تصميمات لتي شيرت الأطفال "

رسالة ماجستير غير منشورة - كلية التربية النوعية - جامعة طنطا -

$$
.5+1 .
$$

فاطمة إسماعيل محمد : لدراسة تأثير المنظفات الصناعية المحلية علي الخواص الأدائية

للأقمشة الصوفية والصوفية المخلوطة " رسالة ماجستير غير منشورة كلية التربية النوعية - جامعة المنوفية ، 2010 م .

"وحدة تعليمية [ CD ] في مجال تصميم وطباعة الملابس الجاهزة

مريم نبيل شكر الله

بهذف تطوير بعض مناهج الطباعة بالمعاهد المتخصصة " رسالة

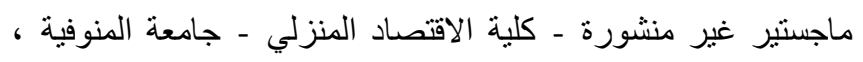

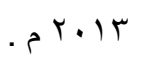

: :

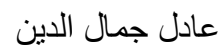

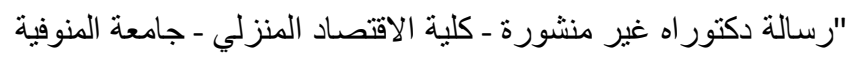

: : : بعض مشكلات الطباعة اليدوية للأقمشة الصناعية الداكنة للوصول إلي توفيق مصطفي محمد أفضل جودة للمنتج النهائي للتطبيق في الصناعة " رسالة ماجستير غير منشورة - كلية الاقتصاد المنزلي - جامعة المنوفية ، ب ا ـ ب م . 